\title{
Impact of Moisture Flux and Vertical Wind Shear on Forecasting Extreme Rainfall Events in Nigeria
}

\author{
Olumide A. Olaniyan, Vincent O. Ajayi, Kamoru A. Lawal, and \\ Ugbah Paul Akeh
}

\section{Contents}

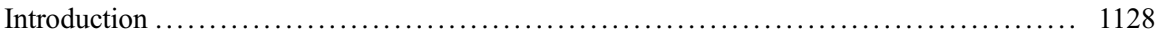

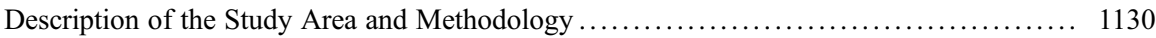

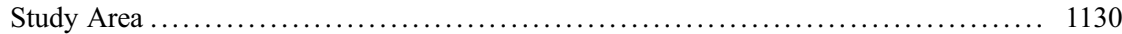

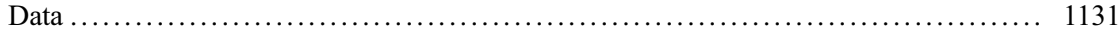

Research Methodology ............................................... 1132

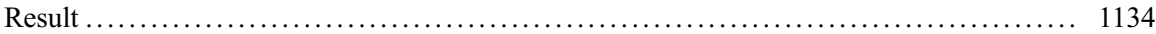

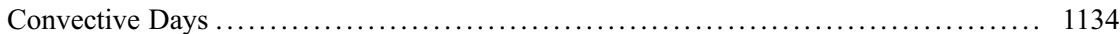

Non-convective Day .............................................. 1145

Mean HMFD and CAPE at the Surface, Three Days Prior and Three Days After Storm

Events ............................................................... 1149

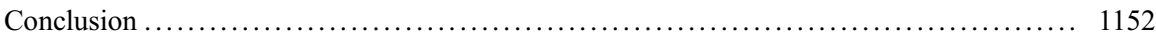

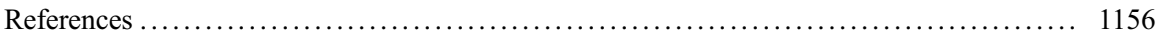

This chapter was previously published non-open access with exclusive rights reserved by the Publisher. It has been changed retrospectively to open access under a CC BY 4.0 license and the copyright holder is "The Author(s)". For further details, please see the license information at the end of the chapter.

O. A. Olaniyan $(\varangle) \cdot$ U. P. Akeh

National Weather Forecasting and Climate Research Centre, Nigerian Meteorological Agency, Abuja, Nigeria

V. O. Ajayi

West African Science Service Center on Climate Change and Adapted Land Use, Federal University of Technology, Akure, Ondo State, Nigeria

Department of Meteorology and Climate Science, Federal University of Technology, Akure, Nigeria e-mail: voajayi@futa.edu.ng

K. A. Lawal

National Weather Forecasting and Climate Research Centre, Nigerian Meteorological Agency, Abuja, Nigeria

African Climate and Development Initiative, University of Cape Town, Cape Town, South Africa 


\section{Abstract}

This chapter investigates extreme rainfall events that caused flood during summer months of June-September 2010-2014. The aim is to determine the impact of horizontal moisture flux divergence (HMFD) and vertical wind shear on forecasting extreme rainfall events over Nigeria. Wind divergence and convective available potential energy (CAPE) were also examined to ascertain their threshold values during the events. The data used include rainfall observation from 40 synoptic stations across Nigeria, reanalyzed datasets from ECMWF at $0.125^{\circ} \times 0.125^{\circ}$ resolution and the Tropical Rainfall Measuring Mission (TRMM) dataset at resolution of $0.25^{\circ} \times 0.25^{\circ}$. The ECMWF datasets for the selected days were employed to derive the moisture flux divergence, wind shear, and wind convergence. The derived meteorological parameters and the CAPE were spatially analyzed and superimposed on the precipitation obtained from the satellite data. The mean moisture flux and CAPE for some northern Nigerian stations were also plotted for 3 days prior to and 3 days after the storm. The result showed that HMFD and CAPE increased few days before the storm and peak on the day of the storms, and then declined afterwards. HMFD values above $1.0 \times 10^{-6} \mathrm{~g} \mathrm{~kg}^{-1} \mathrm{~s}^{-1}$ is capable of producing substantial amount of rainfall mostly above $50 \mathrm{~mm}$ while wind shear has a much weaker impact on higher rainfall amount than moisture availability. CAPE above $1000 \mathrm{Jkg}^{-1}$ and $1500 \mathrm{Jk}^{-1}$ are favorable for convection over the southern and northern Nigeria, respectively. The study recommends quantitative analysis of moisture flux as a valuable short-term severe storm predictor and should be considered in the prediction of extreme rainfall.

\section{Keywords}

Mesoscale convective system $\cdot$ Moisture flux divergence $\cdot$ Wind shear $\cdot$ Extreme rainfall $\cdot$ Flood

\section{Introduction}

Human-induced climate change has increased the amount of water vapor in the atmosphere and has caused adverse effects on different regions, ecosystems, and economies across the world (Nwankwoala 2015). These effects depend not only on the sensitivity of populace to climate change but also on their ability to adapt to risks and changes associated with it. Since the atmospheric moisture budget plays an important role in the hydrology of a particular region, the changing weather patterns caused by climate change has increased the incidences of extreme rainfall events (Roshani et al. 2012; Weisman et al. 1988). Rainfall variability associated with climate change has impacted socioeconomic activities such as agriculture, food security, water resources management, health sector, hydroelectric power generation, and dam management among others in Nigeria (Bello 2010). Most of the negative effects of rainfall variability are on agriculture since majority of farmers 
in the country depend on rain-fed agriculture for livelihood (IPCC 2014; Lawal et al. 2016). Levels of adaptation of farmers in Nigeria to climate change is low, due to lack of adequate education, assets, information, and income (Madu 2016), and consequently agriculture is more vulnerable to climate change impact. Rainfall over Nigeria is mostly from the West African Monsoon systems (WAMS) (Diatta and Fink 2014), and agriculture is an important sector of economy of the country which is highly dependent on the WAMS (Raj et al. 2019). Studies have shown that the complexity of the atmospheric dynamics that generate rainfall, temporal and spatial variation of its scale made it difficult to understand and model. Also, the required parameters to predict it are usually complex even for a short-term period (Sumi et al. 2012). Majority of the results of studies conducted on extreme precipitation events over Nigeria showed that there have been some notable increase in intensity of rainfall extremes which usually claim many lives and properties (Okorie 2015).

In recent times, incidences of large storms have become more frequent with increased intensity, especially the occurrences of high rainfall in form of intense single-day events causing devastating flood (Enete 2014). However, short-range forecasting of these flood occurrences has been a great challenge. Studies have also shown that the distinctive property of West African monsoon flow is that there is seasonal, monthly, and daily variability in its moisture content mainly in the lowest $1 \mathrm{~km}$ of the atmosphere (Omotosho and Abiodun 2007). Furthermore, the intensity and duration of extreme rainfall are majorly dependent on the adequacy of moisture carried by the moist southwesterly flow from the South Atlantic Ocean. Studies have also shown that the daily variability of moisture advection mechanisms is responsible for the changes in the intensity and amount of rainfall (Omotosho et al. 2000). Couvreux et al. (2010) noted that at low level, daily moisture transport takes place with periodic northward advection of moisture flux that has 3-5 days frequency. A study conducted by Bechtold et al. (2004) also showed that large-scale thunderstorms in form of Mesoscale Convective Systems (MCSs) are formed over West Africa when there is constant supply of low-level moisture. The action of synoptic scale intensification of the St. Helena high pressure system over the South Atlantic Ocean is majorly responsible for moisture divergence into West Africa. Similarly, in a numerical study of moisture build-up and rainfall done by Omotosho and Abiodun (2007), it was reported that the rainfall amount does not depend on the monsoon flow alone but majorly on the sufficiency and the variability of its moisture content. Other studies have also examined the influence and interaction of different scales of motion such as African Easterly Jet (AEJ), Tropical Easterly Jet (TEJ), and African Easterly Waves (AEW) on the formation of MCSs (Nicholson 2013). These studies focused mainly on the scale interactions responsible for seasonal variability in weather pattern during northern summer (Janicot et al. 2011). They, however, did not consider in detail the quantity of daily moisture advection responsible for these rainfall extremes. The main focus of this chapter is to contribute to the understanding of the impact of moisture flux on the rainfall amount. Hence, it is necessary to study extreme precipitation events and diagnose the signatures of the meteorological parameters peculiar to such events. Studying this may enhance the assessment of the manner in which extreme rainfall events evolve and therefore provide a short-term early warning 
method to forecasters. It will also assist in understanding the evolution of some derived meteorological parameters such as the moisture flux which determines the quantity of rainfall and the wind shear which determines the life span of the storm (Weisman et al. 1988). Thorough understanding of these parameters will aid reliable short-term flood forecast. The usefulness of horizontal moisture flux at or near the earth's surface as a thunderstorm predictor has been recognized throughout various studies (Beckman 1990). Apart from the availability of moisture, sustenance of MCSs also requires a certain magnitude of vertical wind shear to produce a stronger and longer-lived system (Weisman and Rotunno 2004). Observational and numerical studies have revealed that horizontal winds and their vertical structures have important impacts on convective development; to buttress this point, Omotosho (1987) noted that thunderstorms occur, most frequently, in association with low-level wind shears below the AEJ (surface to $700 \mathrm{hPa}$ ) ranging from -20 to $-5 \mathrm{~s}^{-1}$ and for mid troposphere $(700-400 \mathrm{hPa})$ in the range of 0 to $10 \mathrm{~s}^{-1}$. Despite the importance of wind shear, its effect on MCS has not been treated explicitly over Nigeria.

Most climate prediction models do not perform well in prediction of extreme rainfall events over West Africa because of their low resolution (Nyakwada 2004), the nature of parameterization schemes employed in the model, scarcity of real-time data, and mostly due to the convective nature of West African rainfall, hence the forecast of extreme rainfall event is a major challenge to forecasters in West Africa. The aim of this chapter is therefore to determine the impact of moisture flux, vertical wind shear, and other derived meteorological parameters such as wind divergence and convective available potential energy (CAPE) on MCSs during extreme rainfall events over Nigeria. Therefore, the study investigates the spatiotemporal variability of moisture flux that feeds into MCSs and its impacts on the occurrences of high impact rainfall. The objective is to assess the threshold values of derived meteorological parameters responsible for isolated cases of extreme precipitation in order to enhance its predictability and contribute to the understanding of the impact of moisture flux on the amount of precipitation. This research makes use of a synergistic approach involving the moisture flux divergence, wind shear analysis below and above the AEJ, and CAPE. The spatial distribution of these derived parameters is considered, with a focus on understanding their contribution to the formation and sustenance of MCSs during extreme rainfall events. This chapter will be a useful guide for further investigations into accurate prediction of high impact rainfall that can result into flood events using moisture flux analysis.

\section{Description of the Study Area and Methodology}

\section{Study Area}

Nigeria is situated between latitudes $4^{\circ}$ and $14^{\circ} \mathrm{N}$ and longitudes $2^{\circ}$ and $15^{\circ} \mathrm{E}$ and falls within the tropics. It shares borders with Niger in the north, Chad in the northeast, Benin in the west, Cameroon in the east, and its coast in the south borders the Gulf of Guinea on the South Atlantic Ocean. Precipitation is received mainly 


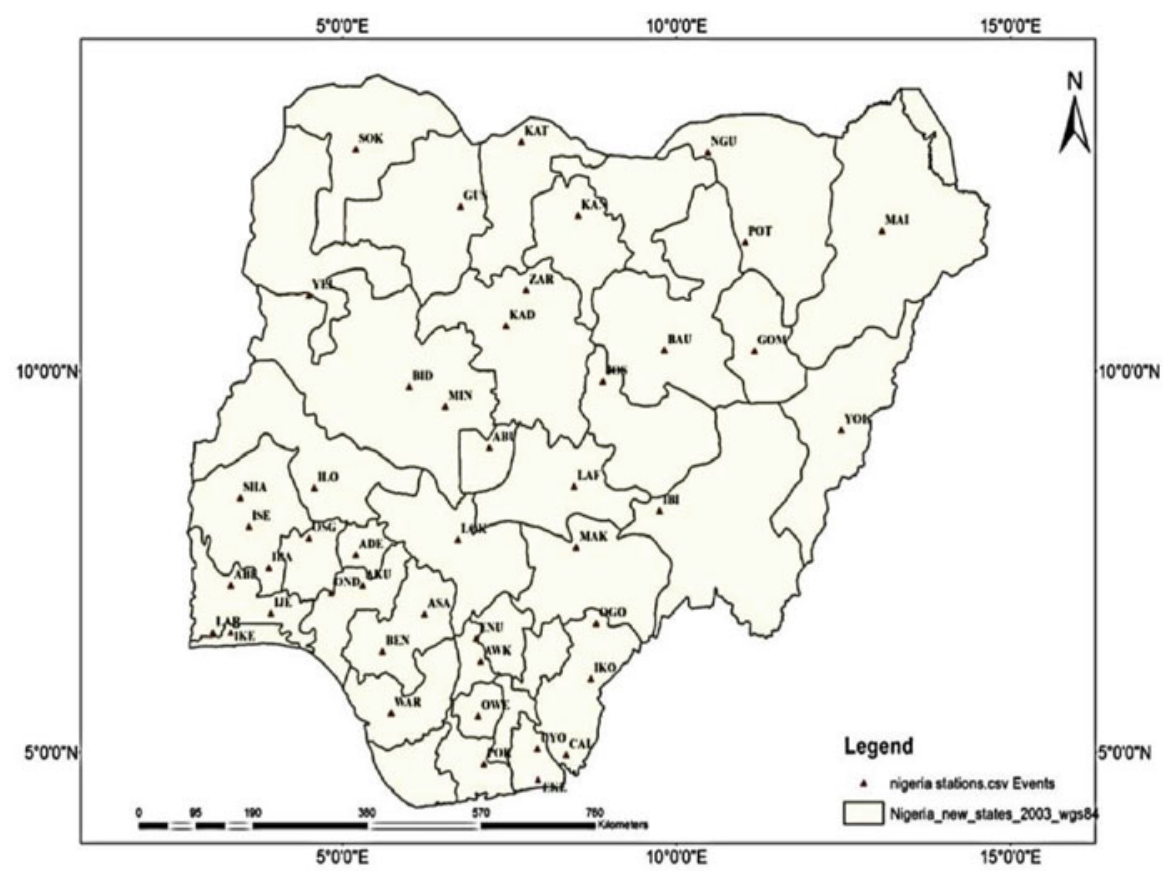

Fig. 1 Map of Nigeria showing the whole country as study area and spatial distribution of Nigerian Meteorological Agency synoptic stations used in this chapter

during the northern hemispheric summer, which is referred to as the wet seasons. Moist southwesterly winds from the South Atlantic Ocean prevail during the summer while dry northeasterlies from the Sahara desert are dominant in the winter which is the dry season (Fig. 1).

The confluence zone between both wind systems is the Inter-tropical Discontinuity (ITD). The surface location of the ITD significantly accounts for rainfall interannual variability in the country (Nicholson 2009). The ITD fluctuates seasonally during the northern summer over West Africa and migrates northward from its winter position of $4^{\circ} \mathrm{N}$ to its northernmost position of about $22^{\circ} \mathrm{N}$ (Fig. 2). The amount of rainfall experienced by different areas depends on the position of the ITD. Most of the convective rainfall follows the south-north-south displacement of the ITD (Sultan and Janicot 2003).

\section{Data}

Daily data for selected days of heavy rainfall was obtained from the European Centre for Medium-Range Weather Forecast's (ECMWF) ERA-INTERIM dataset on a gridded point of $0.125^{\circ} \times 0.125^{\circ}$ and pressure levels of $1000,850,700,400$, and $200 \mathrm{hPa}$ for the summer months of June-September 2010-2014. The daily datasets 


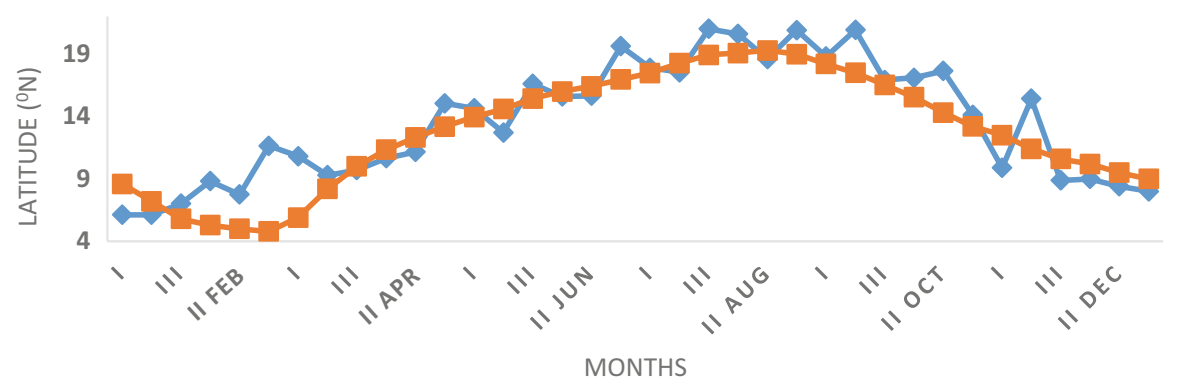

$\longrightarrow$ Obs2018 $\longrightarrow$ Normal

Fig. 2 Decadal latitudinal positions of the ITD in 2018 and its climatological mean over Nigeria. (Source: NiMet Climate Review Bulletin 2018)

are convective available potential energy (CAPE), specific humidity, zonal (U), meridional (V) winds, and divergence. Daily-accumulated rainfall was obtained from Tropical Rainfall Measuring Mission (TRMM) dataset, at a resolution of $0.25^{\circ} \times 0.25^{\circ}$. Observed rainfall for the months of June-September 2010-2014 was obtained from the Nigerian Meteorological Agency (NiMet) from 40 synoptic stations over Nigeria as shown in Fig. 1 to validate the TRMM dataset. Days of unusually high amount of rainfall during the months of June-September were selected from 2010 to 2014 .

\section{Research Methodology}

Derived meteorological parameters such as moisture flux, CAPE, vertical wind shear, monsoon depth, the strengths of AEJ and TEJ were evaluated on these specific days to ascertain the characteristics of atmospheric dynamics during the occurrences of extreme rainfall events. The monsoon depth, the strengths of AEJ and TEJ are obtained by plotting the vertical wind profile using the $U$ component of wind. The atmospheric dynamics of these events were diagnosed to find out the significant threshold of moisture flux, CAPE, vertical wind shear, monsoon depth, the strengths of AEJ and TEJ that may possibly be responsible for such unusually high amount of rainfall. Convective days were compared to a non-convective day to determine the difference in the characteristics of the atmospheric dynamics. Observationally, while there were occurrences of thunderstorms with heavy rainfall on convective days, none occurred on non-convective days. Ten weather events that produce rainfall above $50 \mathrm{~mm}$ were also selected for four meteorological stations over the northern region from 2010 to 2014. The mean of derived parameters such as moisture flux and CAPE 3 days prior and after the rainfall events are calculated to assess their characteristics during the period. $\left(12.00^{\circ} \mathrm{N}, 8.59^{\circ} \mathrm{E}\right)$, Maiduguri $\left(11.83 \mathrm{~N}, 13.15^{\circ} \mathrm{E}\right)$, Sokoto $\left(13.01^{\circ}\right.$ $\left.\mathrm{N}, 5.25^{\circ} \mathrm{E}\right)$, and Yelwa $\left(10.83^{\circ} \mathrm{N}, 4.74^{\circ} \mathrm{E}\right)$ were chosen, because according to Omotosho (1985), about $90 \%$ of rainfall over these stations is attributed to MCSs. 


\section{Computation of Horizontal Moisture Flux and Wind Shear}

Horizontal moisture flux is computed by the following formula.

Using $\mathrm{U}$ and $\mathrm{V}$ components of wind,

$$
\nabla \cdot V=\frac{\partial \mathbf{u}}{\partial \mathbf{x}}+\frac{\partial \mathbf{v}}{\partial \mathbf{y}}
$$

where $\nabla . \mathrm{V}=$ Divergence

Horizontal moisture flux divergence (HMFD) fields were derived from the specific humidity and components of the wind for the surface and $850 \mathrm{hPa}$ by using the following formula:

$$
\mathrm{HMF}=-\left(\boldsymbol{U} \frac{\partial \mathbf{q}}{\partial \mathbf{x}}+\boldsymbol{V} \frac{\partial \mathbf{q}}{\partial \mathbf{y}}\right)+\mathrm{q}\left(\frac{\partial \mathbf{u}}{\partial \mathbf{x}}+\frac{\partial \mathbf{v}}{\partial \mathbf{y}}\right)
$$

where:

$$
\begin{gathered}
\left(\boldsymbol{U} \frac{\partial \mathbf{q}}{\partial \mathbf{x}}+\boldsymbol{V} \frac{\partial \mathbf{q}}{\partial \mathbf{y}}\right) \text { is the Advection term } \\
\left(\mathrm{q} \frac{\partial \mathbf{u}}{\partial \mathbf{x}}+\frac{\partial \mathbf{v}}{\partial \mathbf{y}}\right) \text { is the divergence term }
\end{gathered}
$$

where $(\mathrm{q})$ is the specific humidity, $(\mathrm{u})$ and $(\mathrm{v})$ are zonal and meridional wind speed components of $\mathrm{q}, \mathrm{u}$ and $\mathrm{v}$; the advection term represents the horizontal advection of specific humidity, while the divergence term denotes the product of the specific humidity and horizontal mass convergence. $\frac{\partial}{\partial \mathbf{x}}$ and $\frac{\partial}{\partial \mathbf{y}}$ show the horizontal variation of atmospheric quantities such as specific humidity and wind. The first term in the moisture flux (MF) equation is moisture advection. This term incorporates changes of the moisture field with time or the flux of the moisture field. The moisture advection term, similar to the mass divergence term, incorporates into MF the effects of moisture availability on convection. The second term, mass convergence term incorporates moisture accumulation by multiplying the wind convergence, which is the rate at which the air itself is pooling, by the moisture content of the air (mixing ratio). The mass convergence term is usually the dominant term, and observations have shown that the moisture advection term can significantly contribute to the development and subsequent intensification of storms. By combining the effects of mass convergence as a low-level forcing mechanism with moisture availability, moisture flux incorporates most of the ingredients necessary for convection (Roshani et al. 2012).

Vertical wind shear $\left(\mathrm{U}_{\mathrm{S}}\right)$ was calculated using the zonal component of wind at $1000,700,400$, and $200 \mathrm{hPa}$ levels. The vertical wind shear $\left(\mathrm{U}_{\mathrm{S}}\right)$ is defined as:

$$
\mathrm{U}_{\mathrm{S}}=\frac{\mathbf{d u}}{\mathbf{d z}} \mathrm{S}^{-1}
$$


The vertical wind shear at the lower, mid, and upper troposphere using the formula (Omotosho 1987):

$$
\begin{gathered}
\mathrm{U}_{\mathrm{S}(\mathrm{L})}=\mathrm{U}_{700}-\mathrm{U}_{\text {surface }} \\
\mathrm{U}_{\mathrm{S}(\mathrm{M})}=\mathrm{U}_{400}-\mathrm{U}_{700} \\
\mathrm{U}_{\mathrm{S}(\mathrm{U})}=\mathrm{U}_{200}-\mathrm{U}_{400}
\end{gathered}
$$

where:

$\mathrm{U}_{\mathrm{S}(\mathrm{L})}=$ Wind shear at lower troposphere

$\mathrm{U}_{\mathrm{S}(\mathrm{M})}=$ Wind shear at mid troposphere

$\mathrm{U}_{\mathrm{S}(\mathrm{U})}=$ Wind shear at upper troposphere

Rainfall events that produced rainfall above $50 \mathrm{~mm}$ were also selected for four meteorological stations over the northern Nigerian region from 2010 to 2014. The mean of derived moisture flux and CAPE 3 days prior and after the rainfall events were calculated to assess their characteristics during the period. Kano $\left(12.00^{\circ} \mathrm{N}\right.$, $\left.8.59^{\circ} \mathrm{E}\right)$, Maiduguri $\left(11.83^{\circ} \mathrm{N}, 13.15^{\circ} \mathrm{E}\right)$, Sokoto $\left(13.01^{\circ} \mathrm{N}, 5.25^{\circ} \mathrm{E}\right)$, and Yelwa $\left(10.83^{\circ} \mathrm{N}, 4.74^{\circ} \mathrm{E}\right)$ were chosen, because according to Omotosho (1985), about $90 \%$ of rainfall over these stations is attributed to MCSs.

\section{Result}

\section{Convective Days}

\section{Moisture Flux Analysis}

The study presents the analysis of rainfall events that took place from the first to third July 2014 over most parts of the country. The intense rainfall observed led to flooding which resulted into loss of lives and properties. The TRMM rainfall analysis over the country from first to third as shown by Fig. 3a-c depicted the widespread rainfall across the country during the period. Rainfall amount of 71.5, 104, and $117 \mathrm{~mm}$ was observed on the first to third day, respectively, over Eket $\left(4.65^{\circ} \mathrm{N}, 7.94^{\circ} \mathrm{E}\right)$, a coastal city in the southeastern part of the country. The horizontal moisture flux divergence (HMFD) analysis indicated that divergence of moisture at the surface was from the South Atlantic Ocean for the 3 days considered. Figure $4 \mathrm{a}-\mathrm{c}$ showed that the values of HMFD ranged from 0.10 to $1.05 \times 10^{-6} \mathrm{~g} \mathrm{~kg}^{-1} \mathrm{~s}^{-1}$ on the first day with slight reduction on the second day to $0.85 \times 10^{-6} \mathrm{~g} \mathrm{~kg}^{-1} \mathrm{~s}^{-1}$ while the maximum value of HMFD on the third day was up to $1.25 \times 10^{-6} \mathrm{~g} \mathrm{~kg}^{-1} \mathrm{~s}^{-1}$. This analysis showed that higher the amount of moisture supplied to the storm, the higher the amount of precipitation. The analysis at $850 \mathrm{hPa}$ level as shown by Fig. 5a-c depicted that area of moisture divergence shifted from the coast to mainly over the high grounds of Jos, Mambilla plateaus, and other high 


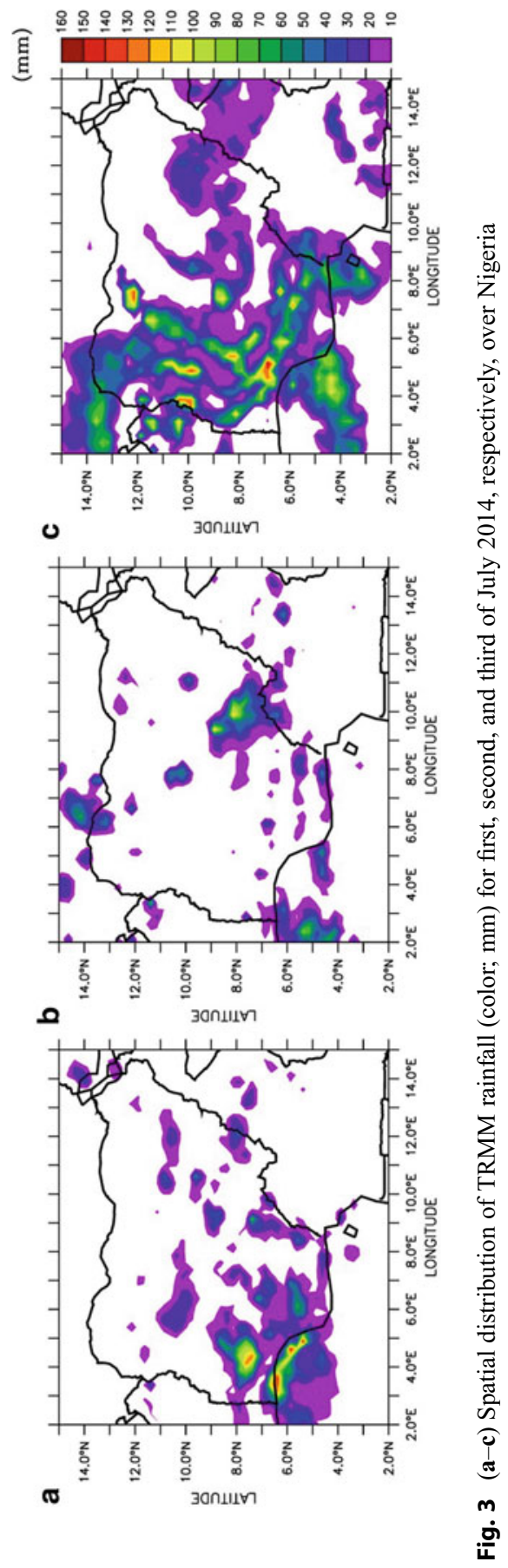



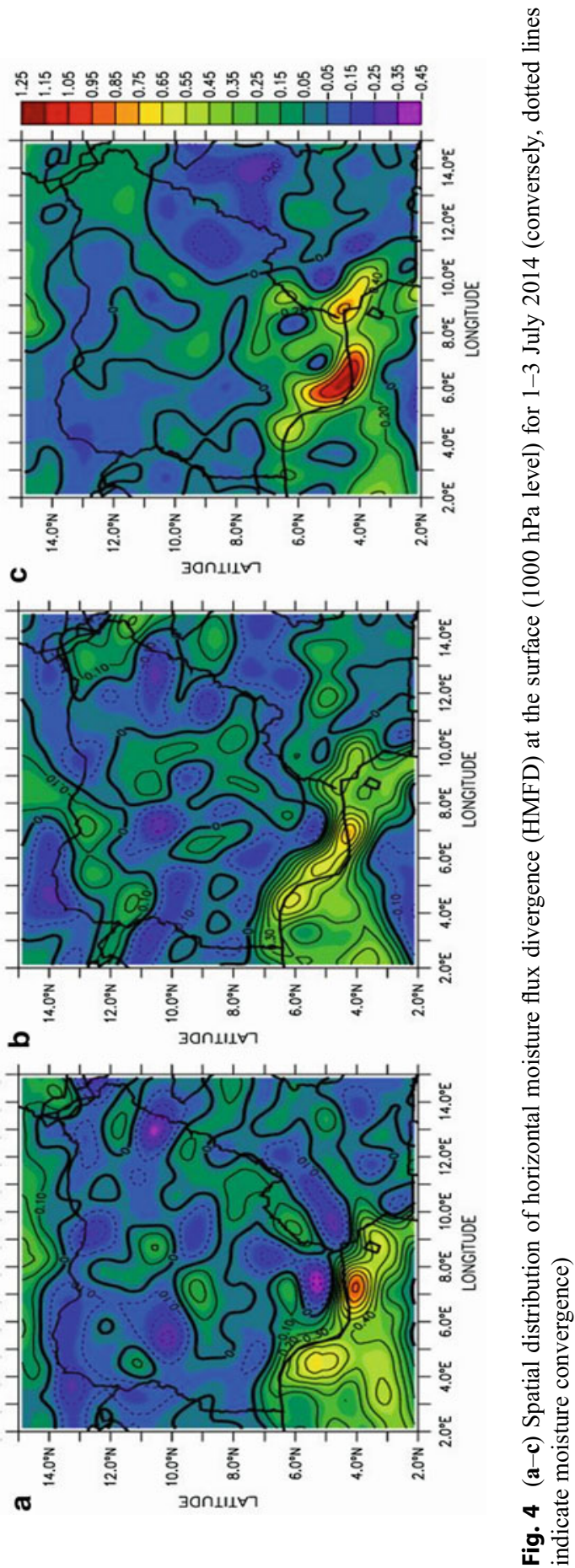


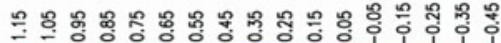

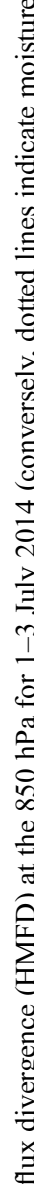

ค
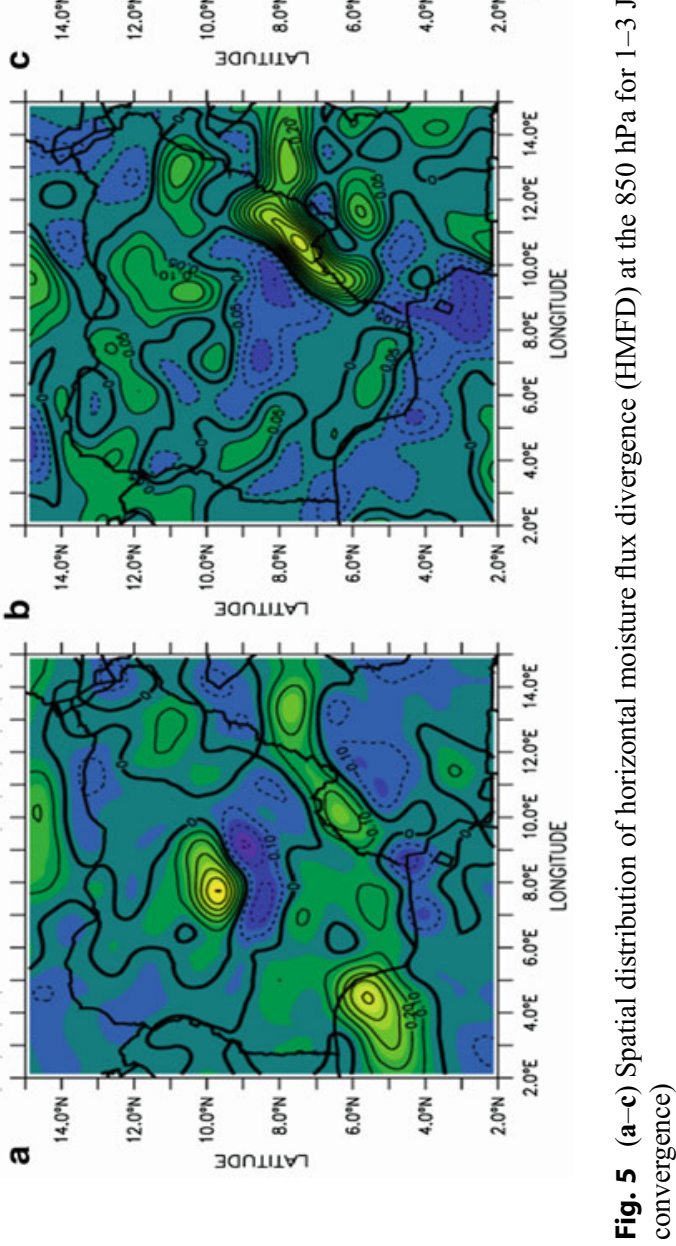
grounds across the country. Values of HMFD ranged from 0.01 to $0.55 \times 10^{-6} \mathrm{~g} \mathrm{~kg}^{-1} \mathrm{~s}^{-1}$ on the first and second day and increased to $1.15 \times 10^{-6} \mathrm{~g} \mathrm{~kg}^{-1} \mathrm{~s}^{-1}$ on the third day. It was observed that close to the divergence areas were areas of strong convergence, which coincided with areas of highest precipitation.

\section{Wind Divergence Analysis}

Figures $6 \mathrm{a}-\mathrm{c}$ and $7 \mathrm{a}-\mathrm{c}$ showed the observed rainfall distribution over the country was maximum along the coastal areas and some inland cities of the southwest, e.g., at Shaki $\left(8.35^{\circ} \mathrm{N}, 5.47^{\circ} \mathrm{E}\right)$ on the first day, strong wind divergence at $200 \mathrm{hPa}$ level exactly over this area enhanced the lower tropospheric wind convergence. This is consistent with Nicholson (2009) which stated that strong upper-level divergence is associated with strong upward motion and severe convective storms; in contrast, upper-level convergence usually indicates downward motion, which is a sign of decaying convection. Due to this strong divergence at the upper level, convection became vigorous and vertical transport of moisture was enhanced from the lower troposphere. However, Fig. 5b shows that along the coast, convergence was observed at the surface with corresponding divergence at $200 \mathrm{hPa}$ with little amount of rainfall; this may also be attributed to insufficient moisture as shown by the moisture flux analysis. Similarly, over the western parts of the country, wind divergence was at the surface with corresponding convergence at $200 \mathrm{hPa}$, hence less precipitation was observed.

\section{Vertical Wind Shear}

The wind shear analysis, Fig. 8a-c showed that the low-level wind shear $\mathrm{Us}_{(\mathrm{L})}$ ranged between $-4 \mathrm{~s}^{-1}$ and $-14 \mathrm{~s}^{-1}$ across the country. These values agreed with Omotosho (1987) who showed that thunderstorms occur most frequently in association with low-level shears, below the African Easterly Jet (i.e., surface to $700 \mathrm{hPa}$ ) with values within $-20 \sim<\mathrm{Us}_{(\mathrm{L})} \sim<-5 \mathrm{~s}^{-1}$. Areas with precipitation value above $50 \mathrm{~mm}$ have values of Us (L) of $-14 \mathrm{~s}^{-1}$ and above. However, some areas with $\mathrm{Us}_{(\mathrm{L})}$ of $-14 \mathrm{~s}^{-1}$ did not record any rainfall, this may be attributed to wind divergence observed at the surface or inadequate moisture supply (Grist and Nicholson, 2001). The value of Us (L) ranges from -8 to $-4 \mathrm{~s}^{-1}$ over the southwest on the first and second day and up to $-12 \mathrm{~s}^{-1}$ on the third day. Considerable amount of rainfall observed over these regions coincided with areas with adequate moisture flux convergence on the first and third day. According to Rotunno et al. (1988) and Weisman et al. (1988), vertical wind shear is important in the formation of organized long-lived convection; however, very strong horizontal wind shear can inhibit the growth of cumulus clouds by blowing away the parts of the cloud containing the best developed precipitation particle and thereby preventing the process of precipitation (Rickenbach et al. 2002). Figure $8 \mathrm{a}-\mathrm{c}$ showed that the value of mid-level wind shear $\mathrm{Us}_{(\mathrm{U})}$ over the country ranges between 0 and $2 \mathrm{~s}^{-1}$ except on the second day where the value of $\mathrm{W}_{\mathrm{S}} \mathrm{U}$ over western parts is between 0 and $-10 \mathrm{~s}^{-1}$. It is noteworthy that moderately sheared environment is important for sustaining MCSs during extreme rainfall event (Figs. 9 and 10). 


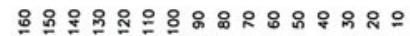

自

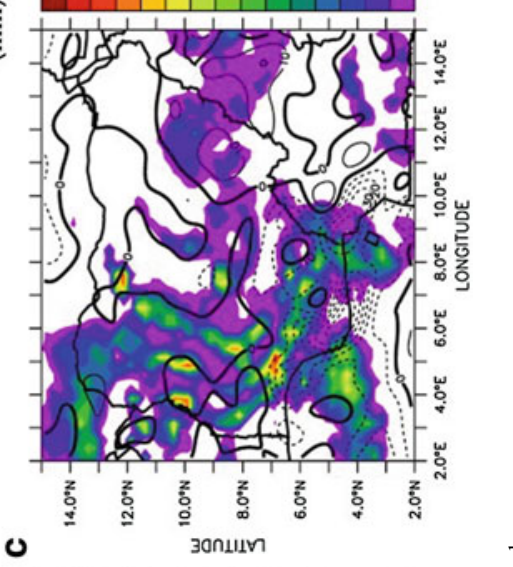

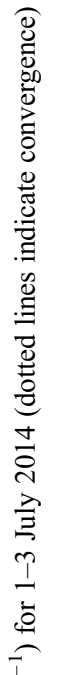
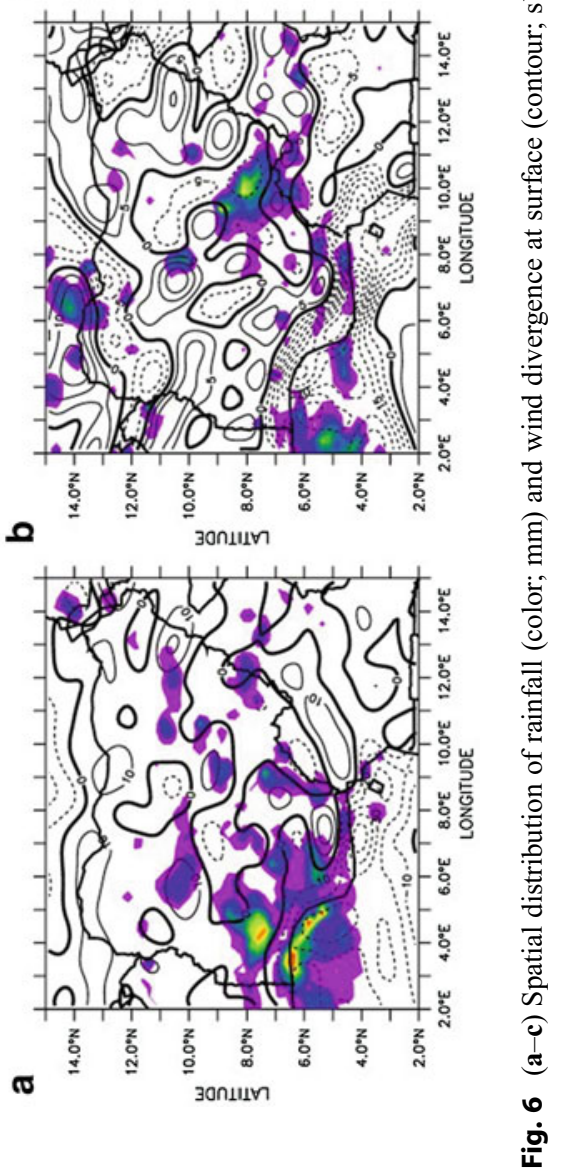


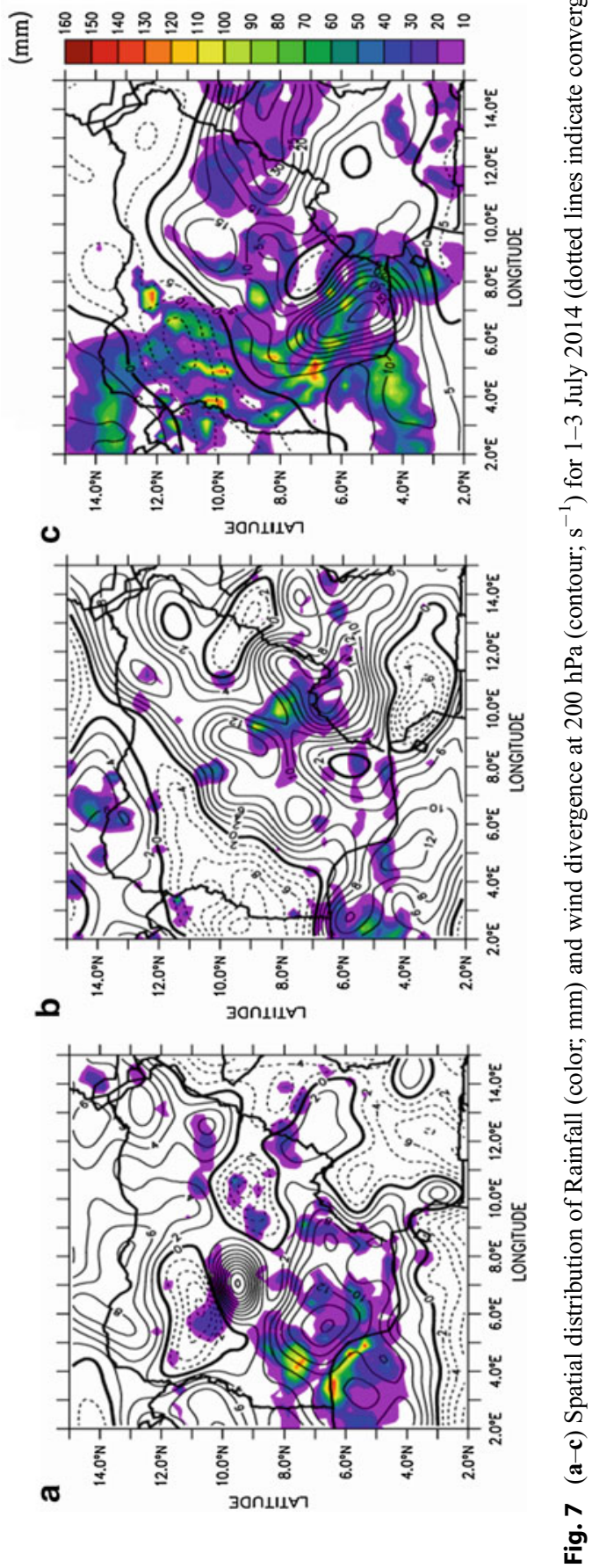



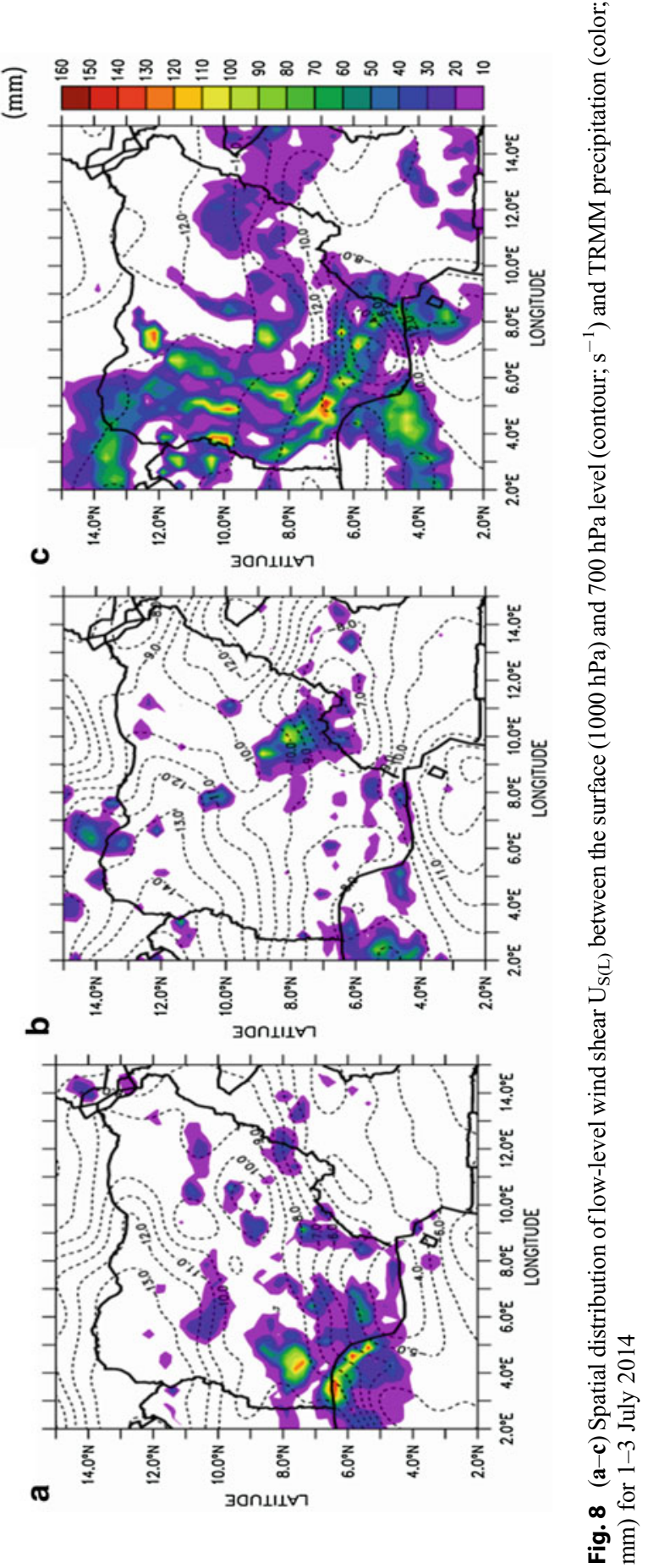

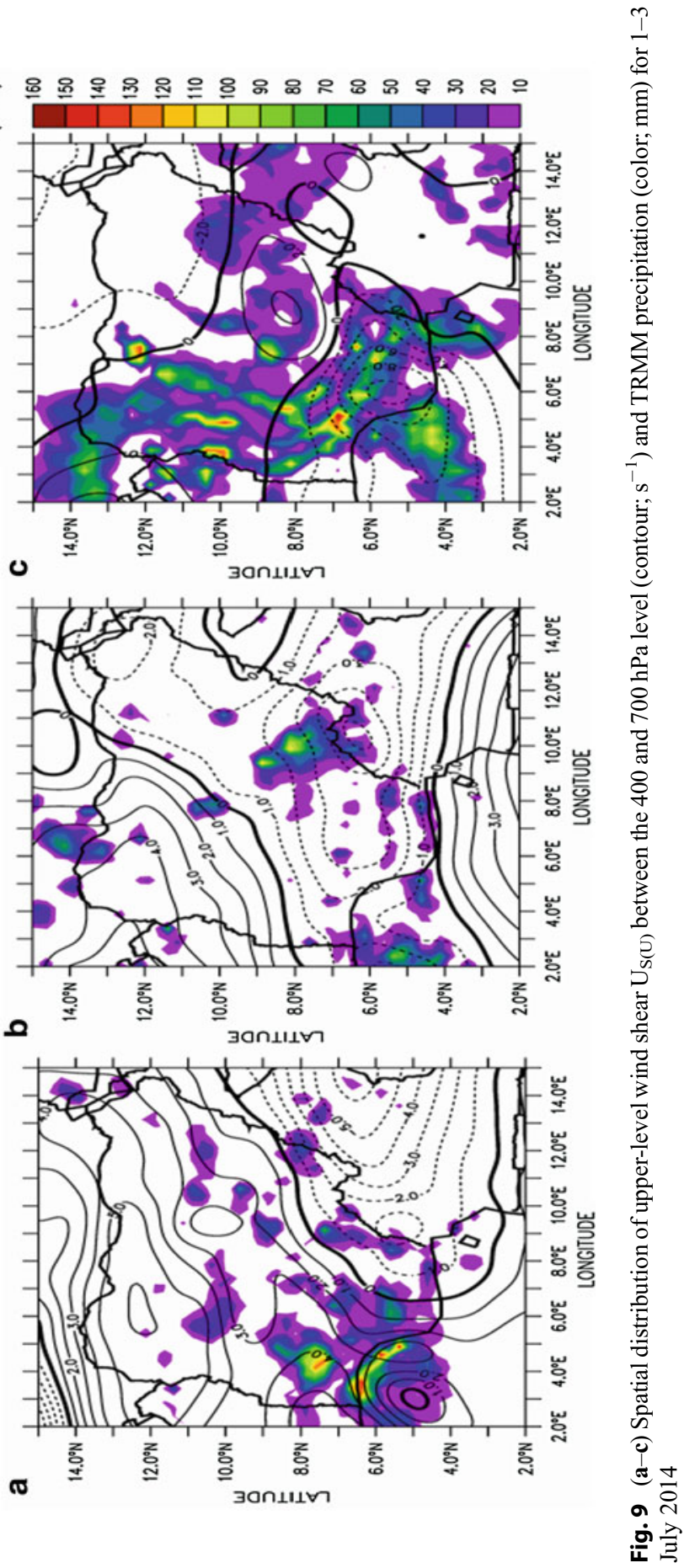
트

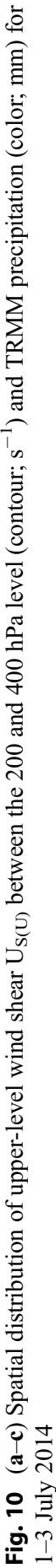




\section{Wind Vector at $850 \mathrm{hPa}$}

Figure $11 \mathrm{a}-\mathrm{c}$ showed that there was continuous moisture supply from the Atlantic Ocean throughout the rainfall events. Moist southwesterly winds convergence that was observed along the southwest coast on the first day produced significant amount of rainfall over Lagos $\left(6.52^{\circ} \mathrm{N}, 3.37^{\circ} \mathrm{E}\right)$ and Lokoja $\left(7.80^{\circ} \mathrm{N}, 6.73^{\circ} \mathrm{E}\right)$ axis. The wind flow from south to north remained steady from the day 1 and 2. Although over the northern parts, the wind direction indicated northeasterly flow on day 3 , but sufficient residual moisture has already accumulated over the country up to the northern areas before the occurrence of a more widespread and heavy rainfall on the third day as shown by Fig. (11a-b). On the third day, over the southeastern parts, there was a well-organized deep monsoon flow from the Gulf of Guinea feeding into a vortex over the inland area of the southeastern parts of the country. The advected moisture depth was enough to maintain the active system over the southeastern axis as shown by the HMFD analysis. A total rainfall of $292.5 \mathrm{~mm}$ was recorded round Eket $\left(4.65^{\circ}\right.$ $\mathrm{N}, 7.94^{\circ} \mathrm{E}$ ), the vicinity of the vortex.
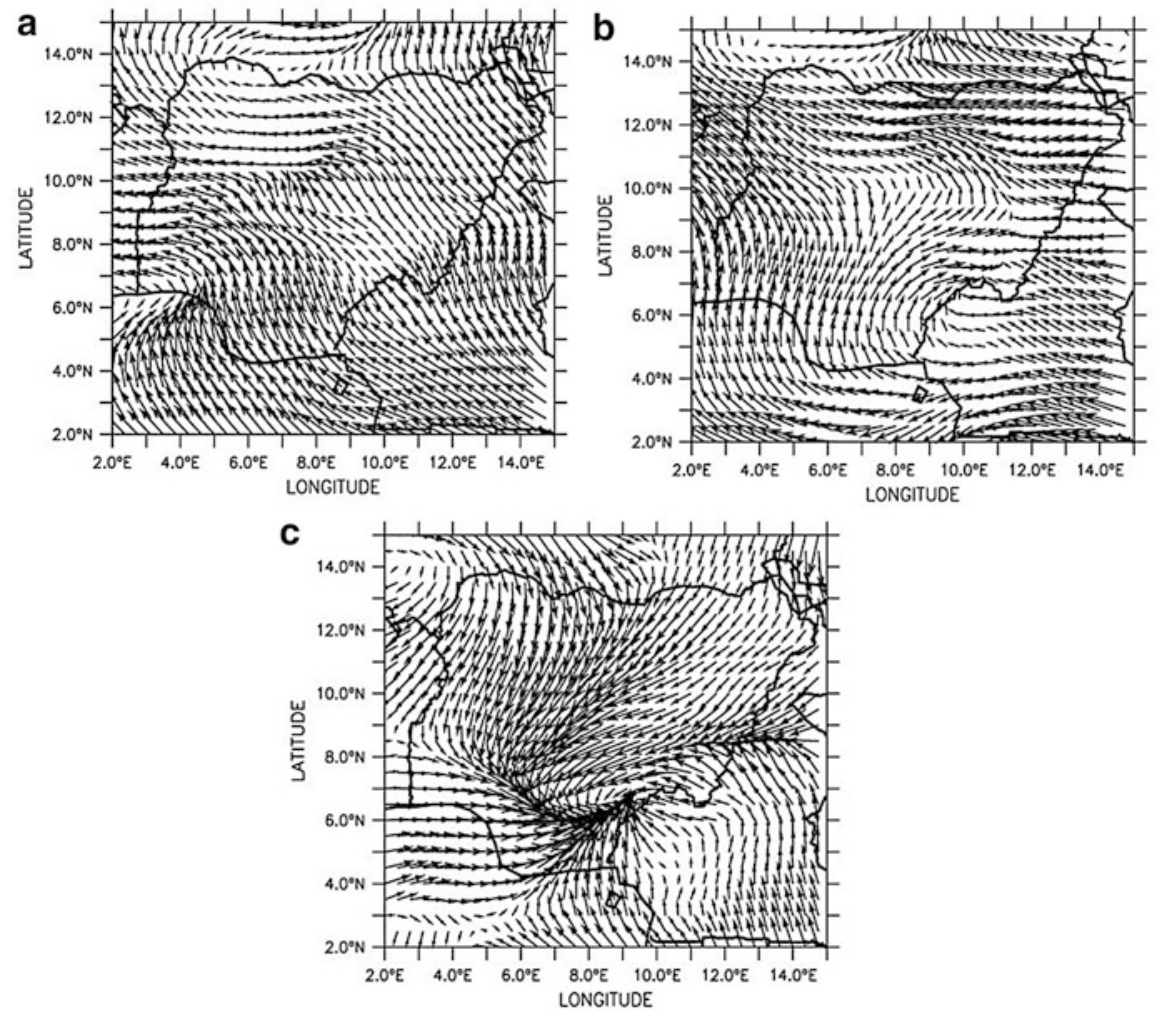

Fig. 11 (a-c): Spatial distribution of wind vector at $850 \mathrm{hPa}$ for 1-3 July 2014 


\section{Convective Available Potential Energy (CAPE)}

CAPE is an energy-based measure of atmospheric stability; it is a very important index in the forecasting of rainfall over Nigeria (Olaniyan et al. 2015). Figure 12a-c showed that the CAPE up to $2900 \mathrm{Jkg}^{-1}$ was observed over the northeast and central parts in the first and second day; however, not much precipitation was recorded. This may also be attributed to insufficient moisture as shown by Fig. 4a-b. Over the southwest, CAPE value of $1600 \mathrm{Jkg}^{-1}$ and $2400 \mathrm{Jkg}^{-1}$ was observed on the first day and the second day, respectively, but due to reduction in moisture flux on the second day, rainfall reduction was observed compared to the first day. Over the southeastern parts, the CAPE values vary from $800 \mathrm{JKg}^{-1}$ to $1600 \mathrm{JKg}^{-1}$ and $1000-1500 \mathrm{Jkg}^{-1}$ on the first and second day, respectively, while on the third day, the value ranged from $1000 \mathrm{JKg}^{-1}$ to $1500 \mathrm{JKg}^{-1}$, and the highest amount of rainfall was observed on the third day. Over the northern parts, CAPE values favorable for convection ranges between 1000 and $2800 \mathrm{Jkg}^{-1}$ on the first day, while it is $600-3000 \mathrm{Jkg}^{-1}$ on the second day though no rainfall was observed on this day due to reduced moisture flux. On the third day, the CAPE value was $2500 \mathrm{Jkg}^{-1}$ and peaked to $4000 \mathrm{Jkg}^{-1}$, higher rainfall was observed due to abundant moisture over this area indicating a deep layer of moisture to fuel the MCSs. A consistent pattern of CAPE was observed throughout the rainfall events, CAPE increases from coastal to the northern parts of Nigeria and the higher the CAPE, the higher the intensity of storm, provided moisture is sufficient.

\section{Vertical Wind Profile (AEJ, TEJ, and Monsoon Depth)}

Figure 13a-c showed the extent of the moist southwesterly winds, the strength of the AEJ and the TEJ over the south and northern regions, and their mean position over the whole country, respectively, from the first to third of July. The zonal wind at the surface was westerly with speed of about 2,6 , and $5 \mathrm{~ms}^{-1}$, respectively, over the south of $9^{\circ} \mathrm{N}$, north of $9^{\circ} \mathrm{N}$, and the entire country. The first and second days indicated lower moisture depth at $900 \mathrm{hPa}$ compared to $950 \mathrm{hPa}$ on the third day (Fig. 13c). The AEJ was located at about $700 \mathrm{hPa}$ with a mean speed of 12, 10, and $8 \mathrm{~ms}^{-1}$ for the first, second, and third day, respectively, while the speed of TEJ was 18,12 , and $13 \mathrm{~ms}^{-1}$, respectively, for the 3 days over the entire country. Thermodynamically, the AEJ is often responsible for advection of both sensible heat and latent energy into regions where severe thunderstorms are formed. TEJ is responsible for enhancing upper level divergence, which in turn encourages vertical motion and lower level convergence (Nicholson et al. 2012). Therefore, the strength of the jets and the availability of adequate moisture support these extreme rainfall events.

\section{Non-convective Day}

Generally, the atmosphere was stable on this day; most stations in the country reported no rainfall. Analysis of a non-convective day was done to evaluate the 

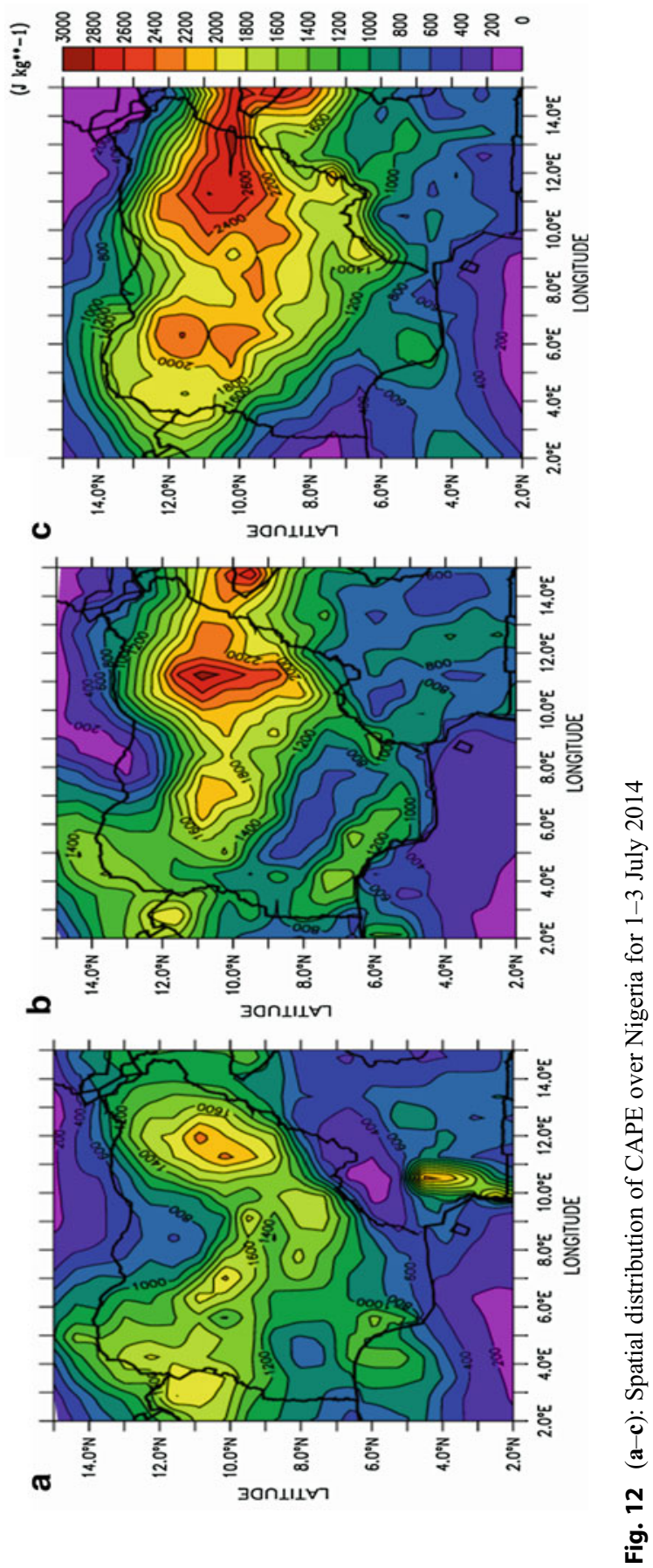

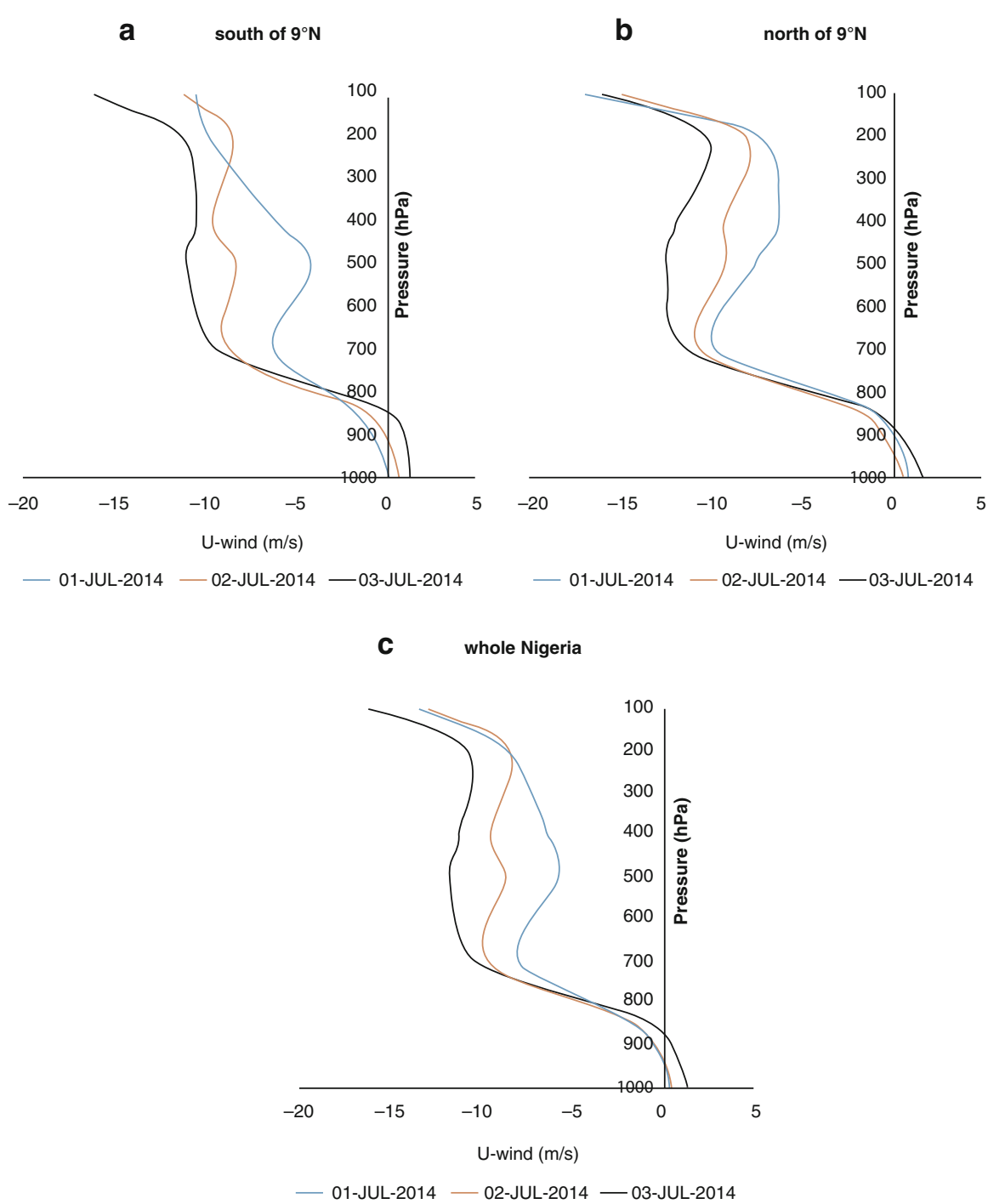

Fig. 13 (a-c) Vertical wind profiles (in $\mathrm{m} / \mathrm{s}$ ) averaged over (a) south of $9^{\circ} \mathrm{N},(\mathbf{b})$ north of $9^{\circ} \mathrm{N}$, and (c) the entire Nigeria for 1-3 July 2014. Days 1,2, and 3 are indicated in blue, red, and gray lines, respectively

difference in the behavior of the convective parameters in order to identify the reason for the observed stability in the atmosphere on the day.

\section{Divergence Analysis}

Figure $14 \mathrm{a}, \mathrm{b}$ shows that over the southwestern parts of the country, convergence was observed at the surface and also at $200 \mathrm{hPa}$, and hence vertical motion was 

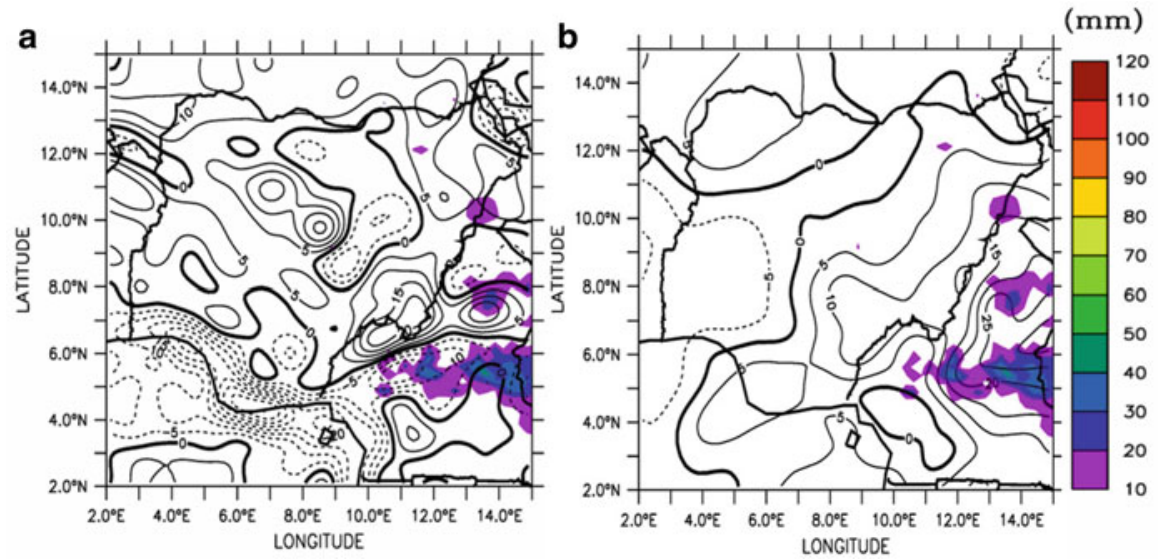

Fig. 14 Spatial distribution of rainfall (color; $\mathrm{mm}$ ) and wind divergence at (a) $1000 \mathrm{hPa}$ (b) $200 \mathrm{hPa}$ level (contour; $\mathrm{s}^{-1}$ ) for 27 August 2014 (dotted lines indicate convergence)

suppressed; this may be due to widespread subsidence prominent during this period caused by reduced sea surface temperature and the ridging effect of the south Atlantic high pressure system over the St. Helena. This period is usually referred to as the little dry season. However, over some parts of the central region and the southeastern coast, convergence was observed at the surface while there was corresponding divergence at $200 \mathrm{hPa}$, but no rainfall was observed; this may be due to lack of sufficient moisture as shown by the HMFD (as shown in the next section) analysis. The rest of the country was prevailed by convergence at $200 \mathrm{hPa}$ while divergence was observed at the surface. These features could suppress vertical transport of moisture.

\section{Moisture Flux Analysis}

The HMFD analysis at the surface in Fig. 15a shows that less moisture was available at the surface and $850 \mathrm{hpa}$ level. Moisture flux diverging from the Atlantic Ocean at the surface over the southwest coast was almost negligible, while over the southeastern part extended from the coast even to the inland has values ranging from 0.10 to $0.55 \times 10^{-6} \mathrm{~kg} / \mathrm{gs}^{-1}$. Although wind convergence is present at the surface with corresponding divergence at $200 \mathrm{hPa}$, moisture may not be sufficient as shown in Fig. 14b, hence no rainfall is observed over the country.

\section{Vertical Wind Shear Analysis}

Figure 16a-c shows that $\mathrm{U}_{\mathrm{S}(\mathrm{L})}$ values ranged between $0 \mathrm{~s}^{-1}$ and $-12 \mathrm{~s}^{-1}$. The value of $U_{\mathrm{S}(\mathrm{M})}$ across the country ranged from $0 \mathrm{~s}^{-1}$ to $-8 \mathrm{~s}^{-1}$, zero value was observed over the central state, while the value of $\mathrm{U}_{\mathrm{S}(\mathrm{U})}$ ranged from $-8 \mathrm{~s}^{-1}$ to $-18 \mathrm{~s}^{-1}$ as shown in Fig. 15a-c. Although this range is conducive for storm initiation, provided other conditions such as moisture availability, lower level convergence, and upper level divergence are met; otherwise, convection may be suppressed. 

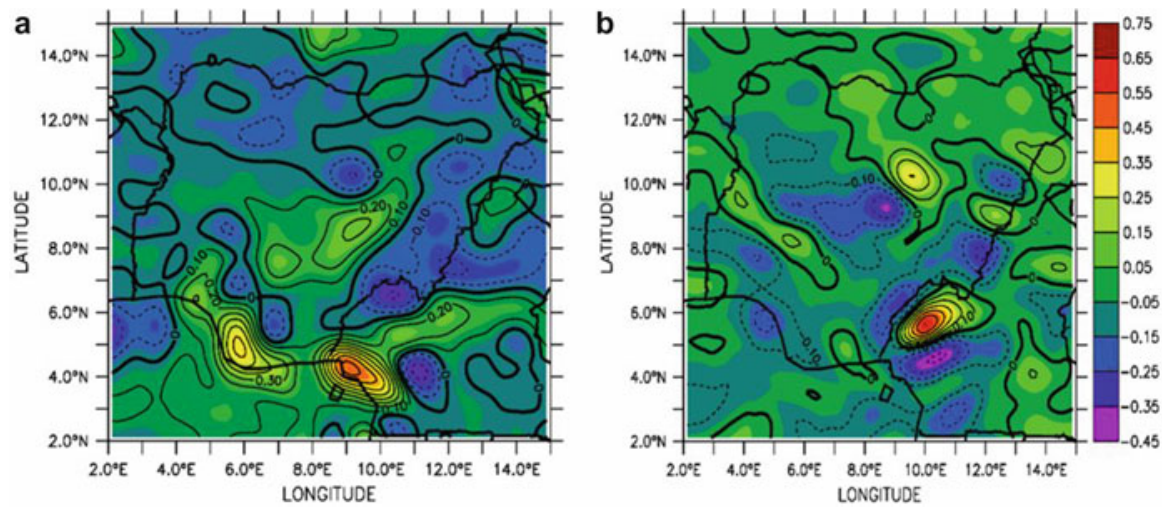

Fig. 15 (a and b) Spatial distribution of horizontal moisture flux divergence (HMFD) at the surface $(1000 \mathrm{hPa})$ and $850 \mathrm{hPa}$ for 27 August 2014 (conversely, dotted lines indicate moisture convergence)

\section{Wind Vector}

The wind vector analysis shown in Fig. 17 depicted the prevalence of southwesterly wind from the Atlantic Ocean, but no rainfall was over the country; this was confirmed by insufficient moisture as shown in the moisture flux analysis of Fig. $15 \mathrm{a}, \mathrm{b}$ despite the fact that the entire country was prevailed by southwesterly winds, and no rainfall was recorded across the country. According to Omotosho and Abiodun (2007), little or no precipitation is observed below a certain limit of atmospheric moisture.

\section{Convective Available Potential Energy (CAPE)}

Figure 18 shows that the CAPE across the country ranges between $200 \mathrm{Jkg}^{-1}$ in the south and $1200 \mathrm{Jkg}^{-1}$ over the north; this is an indication of less potential energy to support convection, and for this particular day, moisture was also not sufficient to support rainfall as shown by HMFD analysis (Fig. 15a, b).

\section{Mean HMFD and CAPE at the Surface, Three Days Prior and Three Days After Storm Events}

Ten weather events that produce rainfall above $50 \mathrm{~mm}$ were selected for four meteorological stations over the northern Nigeria from 2010 to 2014. The mean of derived parameters for selected days namely, horizontal moisture flux divergence (HMFD) and CAPE were evaluated 3 days before and 3 days after the storm over the northern stations of Kano $\left(12.00^{\circ} \mathrm{N}, 8.59^{\circ} \mathrm{E}\right)$, Maiduguri $\left(11.83 \mathrm{~N}, 13.15^{\circ} \mathrm{E}\right)$, Sokoto $\left(13.01^{\circ} \mathrm{N}, 5.25^{\circ} \mathrm{E}\right)$, and Yelwa $\left(10.83^{\circ} \mathrm{N}, 4.74^{\circ} \mathrm{E}\right)$ depicted in Figs. $19 \mathrm{a}, \mathrm{b}, 20 \mathrm{a}, \mathrm{b}$, $21 \mathrm{a}, \mathrm{b}$, and 22a, b, respectively. On these figures, horizontal axes represent days; with 0 representing the day of the stormy events while negative and positive values (day) represent, respectively, 3 days prior and 3 days after the storm. Generally, 


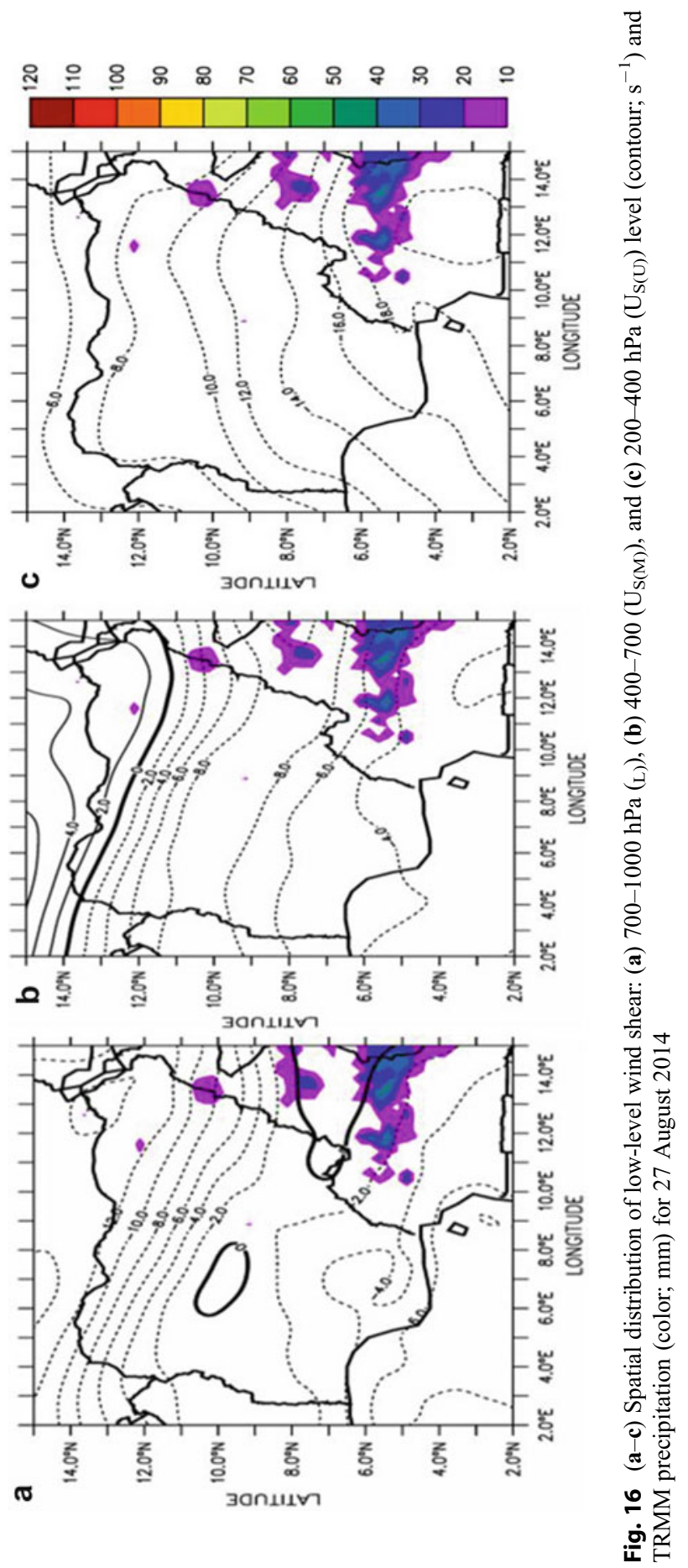




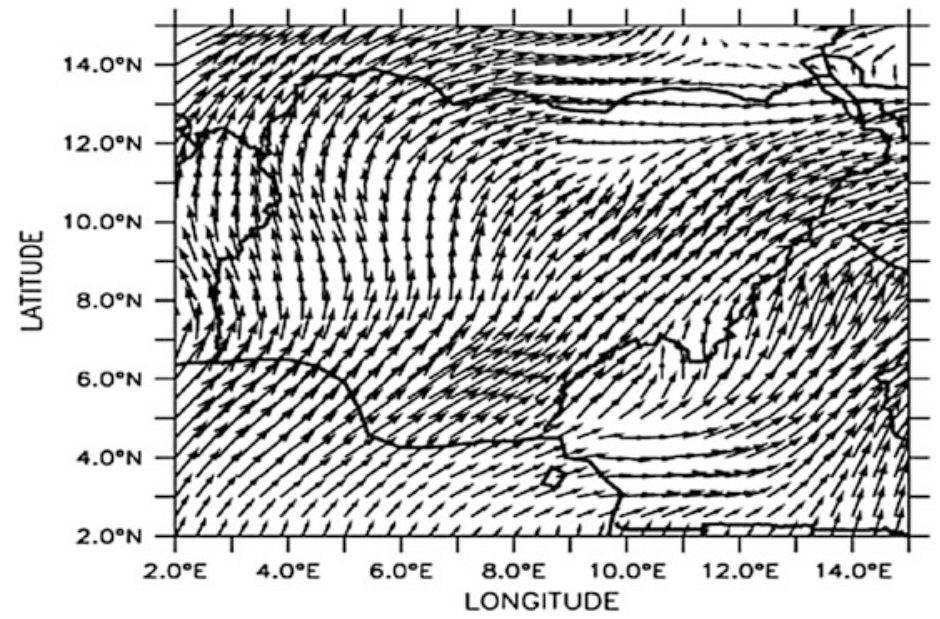

Fig. 17 Spatial distribution of wind vector over Nigeria at $850 \mathrm{hPa}$ for 27 August 2014

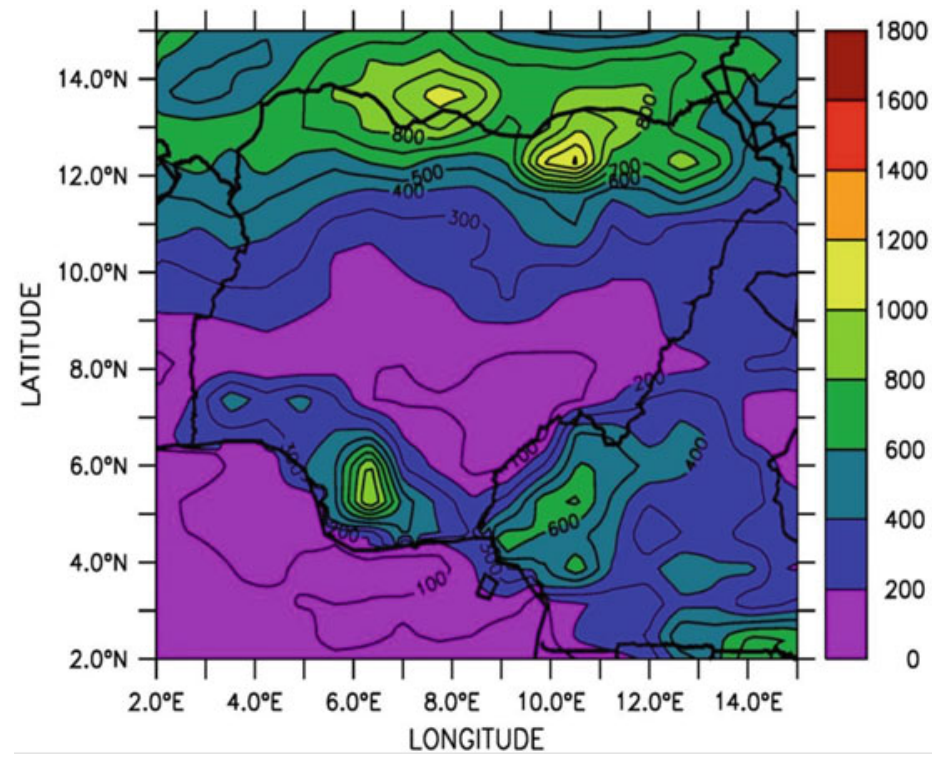

Fig. 18 Spatial distribution of CAPE over Nigeria for 27 August 2014

moisture divergence from the Atlantic Ocean accumulates prior to the storm, reaches climax on the day of the rainfall event, and starts declining after the storm (Panel (a) of Figs. 19, 20, 21, and 22). The mean HMFD was highest on day 0 which is day of the rainstorm. This is depicted by negative moisture flux and afterwards it gradually decreased after the storm. The analysis showed that extreme rainfall events are characterized by significant moisture flux divergence prior to storm events. Panel 
(a)
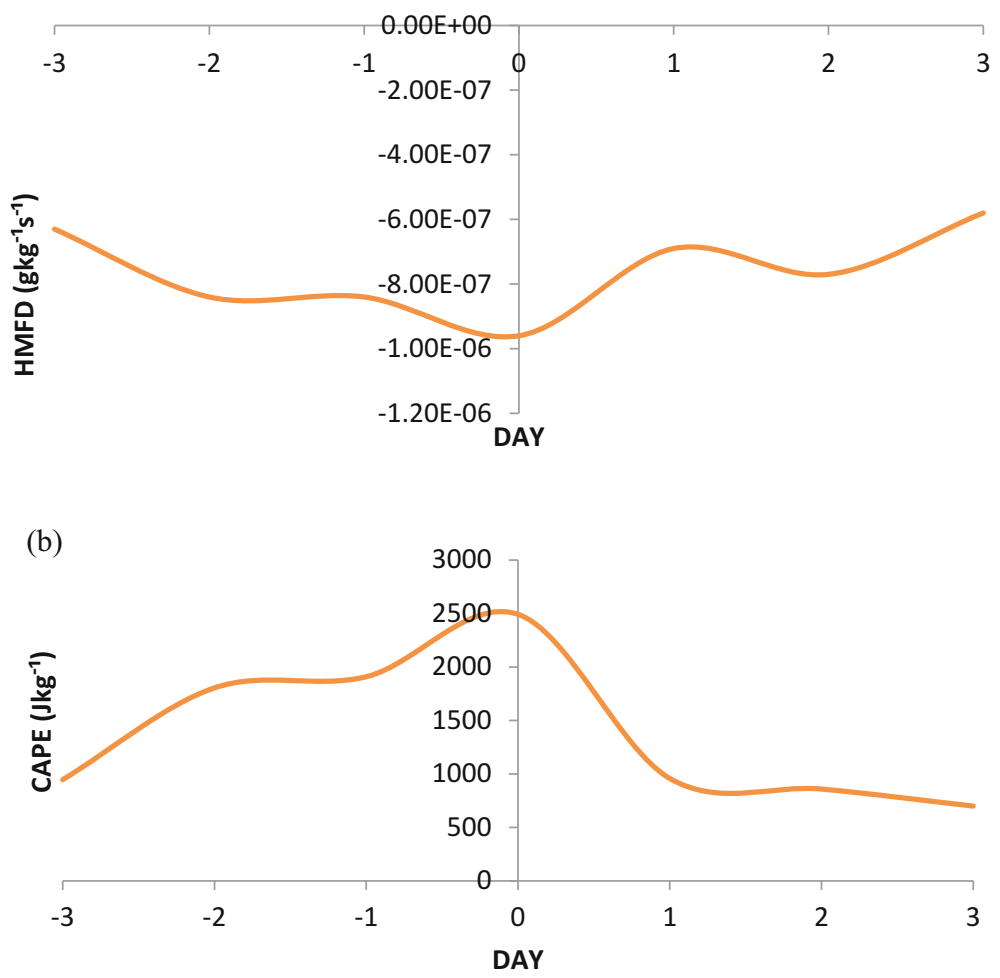

Fig. 19 (a and b) Derived meteorological parameters at surface over Kano (3 days before and 3 days after extreme rainfall events from June to September 2010-2014) for (a) mean HMFD and (b) CAPE

(b) of Figs. 19, 20, 21, and 22 also showed a similar pattern for the mean CAPE analysis.

Table 1 shows the mean CAPE on day 0 , which ranges from $2416 \mathrm{Jkg}^{-1}$ to $2954 \mathrm{Jkg}^{-1}$ with the highest over Sokoto.

\section{Conclusion}

This chapter identified and examined a set of severe widespread rainfall that produced flood events over different parts of Nigeria. The result showed that moisture, convective instability, vertical wind shear, and lifting mechanisms all contributed to these events, but most importantly, the moisture influx. The quantity of rainfall over a given area can be related to the magnitude of the lower tropospheric moisture flux. The study also showed that the transfer of moisture flux in the low layer is mainly from the South Atlantic Ocean, and the higher the moisture flux diverged from the 
(a)

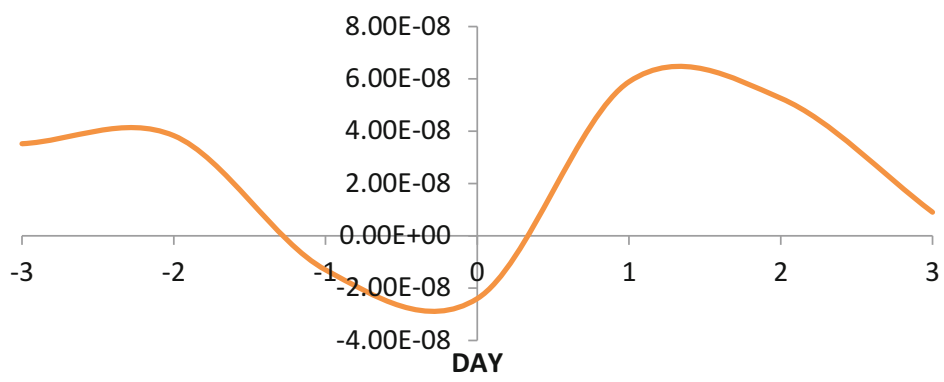

(b)

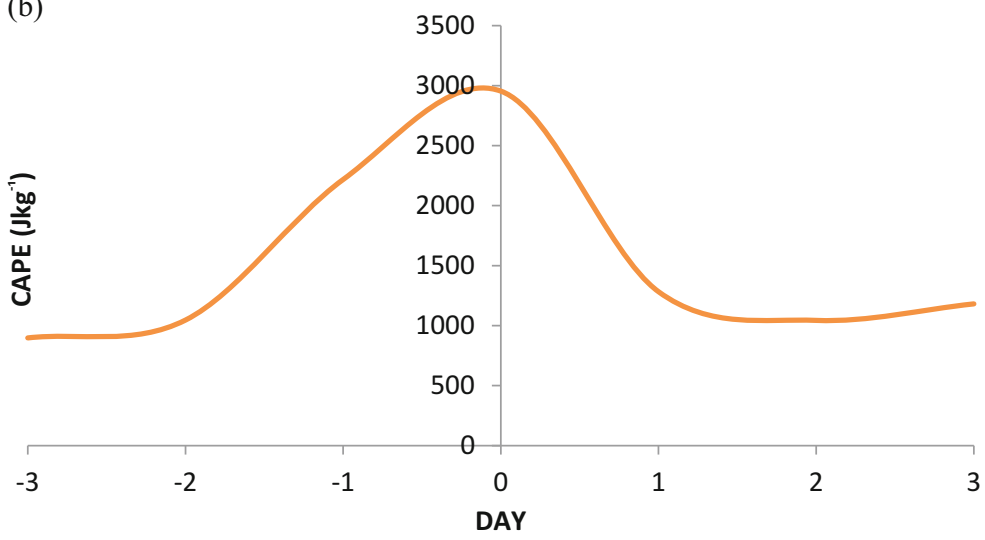

Fig. 20 (a and b) Derived meteorological parameters at surface Sokoto ( 3 days before and 3 days after the storm for extreme events from June to September 2010-2014) for (a) mean moisture flux divergence and (b) CAPE. Negative values in moisture flux analysis indicate convergence while positive values indicate divergence

Atlantic Ocean, the higher the amount of rainfall. The result also indicated that lowlevel convergence that corresponds with upper-level divergence encourages vertical transport of moisture while low-level divergence and upper-level convergence results in subsidence. At the surface, the value of moisture flux divergence ranges between 0.05 and $1.15 \times 10^{-6} \mathrm{gkg}^{-1} \mathrm{~s}^{-1}$ at the vicinity of areas where considerable amount of precipitation of above $50 \mathrm{~mm}$ were observed. They are mostly located westward of moisture divergence zone. This gives a good indication of where flood is most likely. Moisture flux divergence value ranged from 1.0 to $2.0 \times 10^{-6} \mathrm{gkg}^{-1} \mathrm{~s}^{-1}$ at $850 \mathrm{hpa}$ around the areas with substantial amount of rainfall in its vicinity, the high grounds of the southwest, Jos, Mambila, Adamawa plateaus, and Cameroonian mountain are good source of moisture divergence at $850 \mathrm{hPa}$, and hence theses area can be referred to as fertile ground for convection (Hodges and Thorncroft 1997; Akinsanola and Ogunjobi 2014). The wind shear below the AEJ $\left(\mathrm{U}_{\mathrm{S}(\mathrm{L})}\right)$ over 

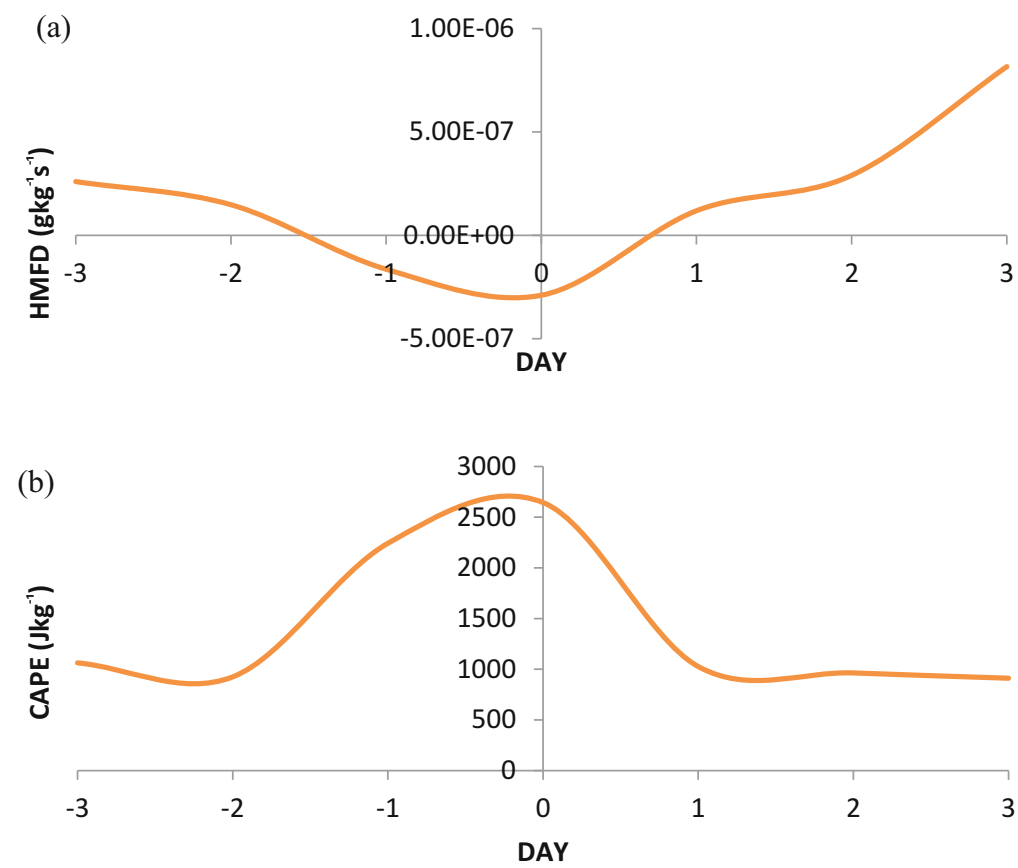

Fig. 21 (a and b) Derived meteorological parameters at surface over Maiduguri (3 days before and 3 days after extreme rainfall events from June to September 2010-2014) for (a) mean moisture flux divergence and (b) CAPE. Negative values in moisture flux analysis indicate convergence while positive values indicate divergence

the region of intense precipitation ranges between -8 and $-12 \mathrm{~ms}^{-1}$. At midtroposphere $\left(\mathrm{U}_{\mathrm{S}(\mathrm{M})}\right)$, wind shear value ranged from $2 \mathrm{~s}^{-1}$ to $-8 \mathrm{~s}^{-1}$, while at upper level $\left(\mathrm{U}_{\mathrm{S}(\mathrm{U})}\right)$, the values ranged between 0 and $12 \mathrm{~s}^{-1}$. Most of the result of $\mathrm{U}_{\mathrm{S}(\mathrm{L})}$ were in agreement with Omotosho (1987) on the value of wind shear necessary for the initiation and sustenance of MCSs.

The CAPE analysis indicated that potential energy equal or greater than $1500 \mathrm{Jkg}^{-1}$ favored convection over the northern parts, while CAPE value equal or greater $1000 \mathrm{Jkg}^{-1}$ was able to trigger convective activities over the southern parts. The result also showed that extreme rainfall also depends on convective available potential energy CAPE, and the higher the CAPE, the more intense was the rainfall, provided moisture was sufficient. Similarly, rainfall observed at a particular area varies according to the amount of moisture flux advected by the monsoon winds into the area. The mean moisture flux and CAPE analysis for extreme storm events over selected cities in northern Nigeria indicated that there is always an increase in the value of moisture flux and CAPE 3 days prior to storm occurrences. This can be a good indicator for forecasting extreme rainfall events. Table 1 shows the peak values of mean CAPE and moisture flux over the selected northern Nigerian stations. The result also shows that sufficient CAPE and wind 
(a)

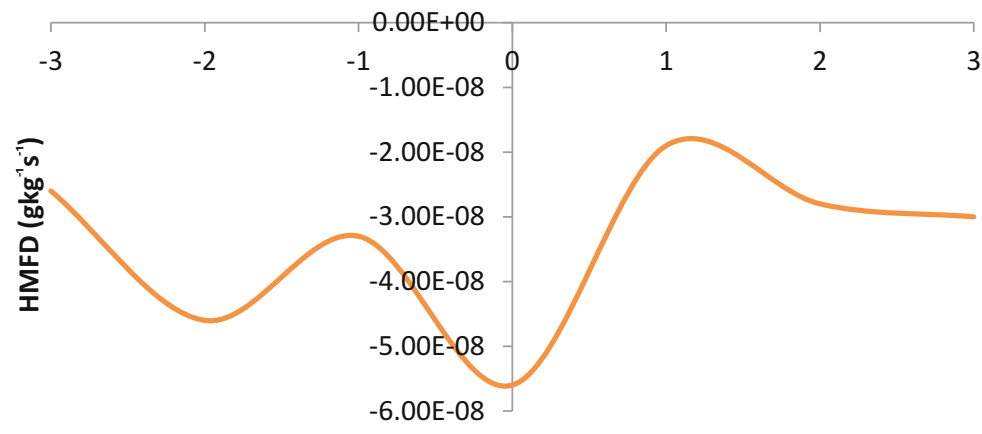

DAY

(b)

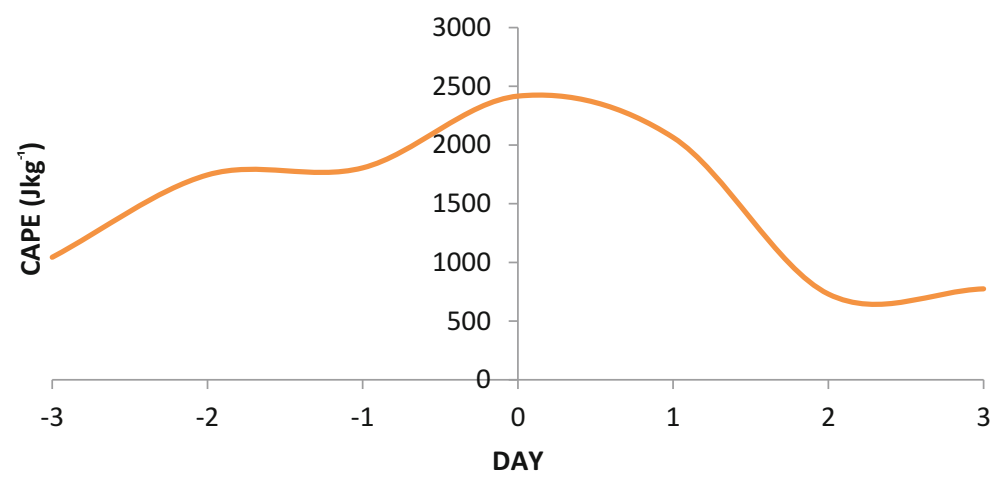

Fig. 22 (a and b) Derived meteorological parameters at surface over Yelwa (3 days before and 3 days after extreme rainfall events from June to September 2010-2014) for (a) mean moisture HMFD and (b) CAPE

Table 1 Peak values of mean derived meteorological parameters at the surface HMFD and CAPE over Kano, Maiduguri, Sokoto, and Yelwa for JJAS (2010-2014)

\begin{tabular}{l|l|l}
\hline STATIONS & HMFD $\left(\mathrm{gKg}^{-1} \mathrm{~s}^{-1}\right)$ & CAPE $\left(\mathrm{Jkg}^{-1}\right)$ \\
\hline KANO & $-9.60 \mathrm{E}-07$ & 2492 \\
\hline MAIDUGURI & $-2.90 \mathrm{E}-07$ & 2644 \\
\hline SOKOTO & $-2.40 \mathrm{E}-08$ & 2954 \\
\hline YELWA & $-5.60 \mathrm{E}-08$ & 2416 \\
\hline
\end{tabular}

shear is not enough for convection, it is necessary to have sufficient amount of moisture for initiation and sustenance of the storm throughout its life. These observed pattern of wind flow at the surface and $850 \mathrm{hPa}$, the CAPE and HMFD when sighted on the forecast charts may be good indicators for forecasting extreme 
rainfall and the likelihood of flood events which will help in early preparedness and prevention of the worst impacts of such extreme events on lives and properties.

A further study of moisture flux and wind shear is recommended using different operational models and more network of stations as this will give a better perception of impact of moisture flux on spatial rainfall variability across the country. Forecasting precipitation amount is a challenging task for forecasters, therefore adequate study of the criteria such as moisture flux, wind shear, and CAPE will increase the understanding of extreme rainfall events; though there will always be variability in the values of meteorological parameters, sound understanding of forecast models, learning how to analyze the situation using the appropriate tools, and knowing how to apply these tools will give the best chance of predicting extreme events and issuing timely warnings.

\section{References}

Akinsanola AA, Ogunjobi KO (2014) Analysis of rainfall and temperature variability over Nigeria. Glob J Hum-Soc Sci: B 14(3):11-17

Bechtold P, Chaboureau J-P, Beljaars A, Betts AK, Kohler “M, Miller M, Redelsperger JL (2004) The simulation of the diurnal cycle of convective precipitation over land in a global model. Q J Roy Meteor Soc 130:3119-3137

Beckman SK (1990) A study of 12 h NGM low-level moisture flux convergence centers and the location of severe thunderstorms/heavy rain. In: Proceedings of the 16th AMS conference on severe local storms, Kananaskis Park, Alta, pp 78-83

Bello NJ (2010) Impacts of climate change on food security in sub-Saharan Africa. In: Proceedings of the 14th Annual Symposium of the International Association of Research Scholars and Fellows, IITA, Ibadan, pp 13-25

Couvreux F, Guichard F, Bock O, Campistron B, Lafore JP, Redelsperger JL (2010) Synoptic variability of the monsoon flux over West Africa prior to the onset. Q J R Meteorol Soc 136 (1):159-173

Diatta S, Fink AH (2014) Statistical relationship between remote climate indices and West African monsoon variability. Int J Climatol 34:3348-3367

Enete IC (2014) Impacts of climate change on agricultural production in Enugu State, Nigeria. J Earth Sci Clim Change 5(9):234. https://www.omicsonline.org/open-access/impacts-of-climatechange-on-agricultural-production-in-enugu-state-nigeria-2157-7617.1000234.php?aid=32633

Grist JP, Nicholson SE (2001) A study of the dynamic factors influencing the rainfall variability in the West African Sahel. J Clim 14(7):1337-1359

Hodges KI, Thorncroft CD (1997) Distribution and statistics of African mesoscale convective weather systems based on the ISCCP Meteosat imagery. Mon Weather Rev 125:2821-2837. https://doi.org/10.1175/1520-0493(1997)125<2821:DASOAM >2.0.CO;2

IPCC (2014) Synthesis report. In: Core Writing Team, Pachauri RK, Meyer LA (eds) Contribution of working groups I, II and III to the fifth assessment report of the Intergovernmental Panel on Climate Change. IPCC, Geneva, 151pp

Janicot S, Caniaux G, Chauvin F, De Coëtlogon G, Fontaine B, Hall N (2011) Intraseasonal variability of the West African monsoon. Atmos Sci Lett 12(1):58-66

Lawal KA, Abatan AA, Anglil O, Olaniyan E, Olusoji Victoria H, Oguntunde PG, Lamptey B, Babatunde JA, Shiogama H, Michael FW, Dith AS (2016) The late onset of the 2015 wet season in Nigeria. BAMS 97:63-69. https://doi.org/10.1175/BAMSD-16-0131.1 
Madu IA (2016) Rurality and climate change vulnerability in Nigeria: assessment towards evidence based even rural development policy. Paper presented at the 2016 Berlin conference on global environmental change, 23-24 May 2016 at Freie Universität Berlin. https://pdfs. semanticscholar.org/508b/94cab07b84a703b44eca1089326cc98d7495.pdf? ga $=2.154518008$. $112403230.1572433568-162569160.1557482164$

Nicholson SE (2009) A revised picture of the structure of the "monsoon" and land ITCZ over West Africa. Clim Dyn 32(7-8):1155-1171

Nicholson SE (2013) The West African Sahel: a review of recent studies on the rainfall regime and its interannual variability. Int Scholar Res Notices 2013:453521, 32 p. https://doi.org/10.1155/ 2013/453521

Nicholson SE, Klotter DA, Dezfuli AK (2012) Spatial reconstruction of semi-quantitative precipitation fields over Africa during the nineteenth century from documentary evidence and gauge data. Quat Res 78:12-23

NiMet Climate Review Bulletin (2018) Nigerian Meteorological Agency 2019

Nwankwoala HNL (2015) Causes of climate and environmental changes: the need for environmental-friendly education policy in Nigeria. J Educ Pract 6(30). http://www.iiste.org. ISSN 2222-1735 (Paper) ISSN 2222-288X (Online)

Nyakwada W (2004) The challenges of forecasting severe weather and extreme climate events in Africa WMO WSHOP-SEEF/Doc.4(4)

Okorie FC (2015) Analysis of 30 years rainfall variability in Imo state of South-Eastern Nigeria. In: Hydrological sciences and water security: past, present and future. IAHS Press, Wallingford, pp $131-132$

Olaniyan E, Afiesimama EOF, Lawal KA (2015) Simulating the daily evolution of West African monsoon using high resolution regional Cosmo-model: a case study of the first half of 2015 over Nigeria. J Climatol Weather Forecast 33:3-8

Omotosho JB (1985) The separate contributions of squall lines, thunderstorms and the monsoon to the total rainfall in Nigeria. J Climatol 5:543-552

Omotosho JB (1987) Richardson number, vertical wind shear, and storm occurrences over Kano Nigeria. Atmos Res 21:123-137

Omotosho JB, Abiodun BJ (2007) A numerical study of moisture build-up and rainfall over West Africa. Meterol Appl 14:209-225

Omotosho JB, Balogun AA, Ogunjobi K (2000) Predicting monthly and seasonal rainfall, onset and cessation of the rainy season in West Africa using only surface data. Int J Climatol 20:865-880

Raj J, Bangalath HK, Stenchikov G (2019) West African monsoon: current state and future projections in a high-resolution AGCM. Clim Dyn 52:6441-6461. https://doi.org/10.1007/ s00382-018-4522-7

Rickenbach TM, Ferreira RN, Halverson J, Silva Dias MAF (2002) Mesoscale properties of convection in Western Amazonia in the context of large-scale wind regimes. J Geophys Res Atmos 107:8040

Roshani A, Fateme P, Zahra H, Hooshang G (2012) Studying the moisture flux over South and Southwest of Iran: a case study from December 10 to 13, 1995 rain storm. Earth Sci Res 2 (2):2013

Rotunno R, Klemp JB, Weisman ML (1988) A theory for strong long lived squall lines. National Center for Atmospheric Research Boulder, Colarado, pp 463-483

Sultan B, Janicot S (2003) The West African monsoon dynamics. Part II: the "preonset" and "onset" of the summer monsoon. J Clim 16:3407-3427

Sumi SM, Zaman MF, Hirose H (2012) A rainfall forecasting method using machine learning models and its application to the Fukuoka City case. Int J Appl Math Comput Sci 22(4):841-854

Weisman ML, Rotunno R (2004) A theory for strong long-lived squall lines revisited. J Atmos Sci 61:361-382. https://doi.org/10.1175/1520-0469(2004)061<0361:ATFSLS > 2.0.CO;2

Weisman ML, Klemp JB, Rotunno R (1988) Structure and evolution of numerically simulated squall lines. J Atmos Sci 45:1990-2013 
Open Access This chapter is licensed under the terms of the Creative Commons Attribution 4.0 International License (http://creativecommons.org/licenses/by/4.0/), which permits use, sharing, adaptation, distribution and reproduction in any medium or format, as long as you give appropriate credit to the original author(s) and the source, provide a link to the Creative Commons license and indicate if changes were made.

The images or other third party material in this chapter are included in the chapter's Creative Commons license, unless indicated otherwise in a credit line to the material. If material is not included in the chapter's Creative Commons license and your intended use is not permitted by statutory regulation or exceeds the permitted use, you will need to obtain permission directly from the copyright holder.

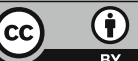

